Pau, C. y Cámara Serrano, J.A. (2019): “Útiles y adornos en materias duras de animales vertebrados de Los Castillejos (Montefrío, España)". Spal 28.2: 51-91. DOI: http://dx.doi.org/10.12795/spal.2019.i28.14

\title{
ÚTILES Y ADORNOS EN MATERIAS DURAS DE ANIMALES VERTEBRADOS DE LOS CASTILLEJOS (MONTEFRÍO, ESPAÑA)
}

\author{
TOOLS AND ORNAMENTS IN VERTEBRATE ANIMAL HARD TISSUES \\ FROM LOS CASTILLEJOS SITE (MONTEFRÍO, SPAIN)
}

\author{
CLAUDIA PAU \\ Dpto. de Prehistoria y Arqueología. Universidad de Granada. \\ Campus Universitario de "Cartuja" s/n. 18071, Granada. \\ Correo-e: claupau@ugr.es, D https://orcid.org/0000-0002-2293-1063 \\ JUAN ANTONIO CÁMARA SERRANO \\ Dpto. de Prehistoria y Arqueología. Universidad de Granada. \\ Campus Universitario de "Cartuja" s/n. 18071, Granada. Tfno. 958249569 \\ Correo-e: jacamara@ugr.es, (D) https://orcid.org/0000-0003-4007-0639
}

\begin{abstract}
Resumen: En este trabajo, exponemos los resultados de los análisis (morfotipológicos, técnicos y traceológicos) de todo el conjunto de artefactos manufacturados en materias duras de animales vertebrados del poblado de Los Castillejos en las Peñas de los Gitanos (Montefrío, Granada, España). Se han establecido 5 categorías (útiles, adornos, ídolos, otros e indeterminados), que se han ulteriormente dividido en grupos, subgrupos y tipos. La materia prima es principalmente local, exceptuando ejemplares de marfil, sobre todo botones de época campaniforme pero también un colgante neolítico. Los huesos largos de animales grandes se usaron para manufacturar útiles y alfileres y los de animales más pequeños para confeccionar colgantes o cuentas. Por traceología se han identificado, principalmente, las últimas fases de manufactura y procesos de reparación y, gracias también a la asociación a ciertos elementos, se ha podido proponer la relación con la actividad textil de punzones laminares y agujas, característicos del Calcolítico.
\end{abstract}

Palabras clave: Neolítico, Calcolítico, Andalucía, industria ósea, análisis tecno-tipológico.
Abstract: We present here the results of the analyses (morphotiphological, technical and traceological) carried out on the assemblage of artefacts manufactured using vertebrate animal hard tissues from Los Castillejos in Las Peñas de los Gitanos site (Montefrío, Granada, Spain). Five categories have been established (tools, ornaments, idols, others and indeterminate items), which have been further divided into groups, subgroups and types. The raw material is mainly local, except for ivory items, mainly Beaker buttons but also a Neolithic pendant. The long bones of greater animals were used to manufacture tools and awls and those of smaller animals to make pendants or beads. By traceology we have mainly identified the last stages of manufacturing and repair processes and, also by the association among certain items, has been proposed the relationship with the textile activity for laminar awls and needles, belonging to the Chalcolithic period.

Keywords: Neolithic, Chalcolithic, Andalusia, Bone Industry, Techno-typological Analysis 


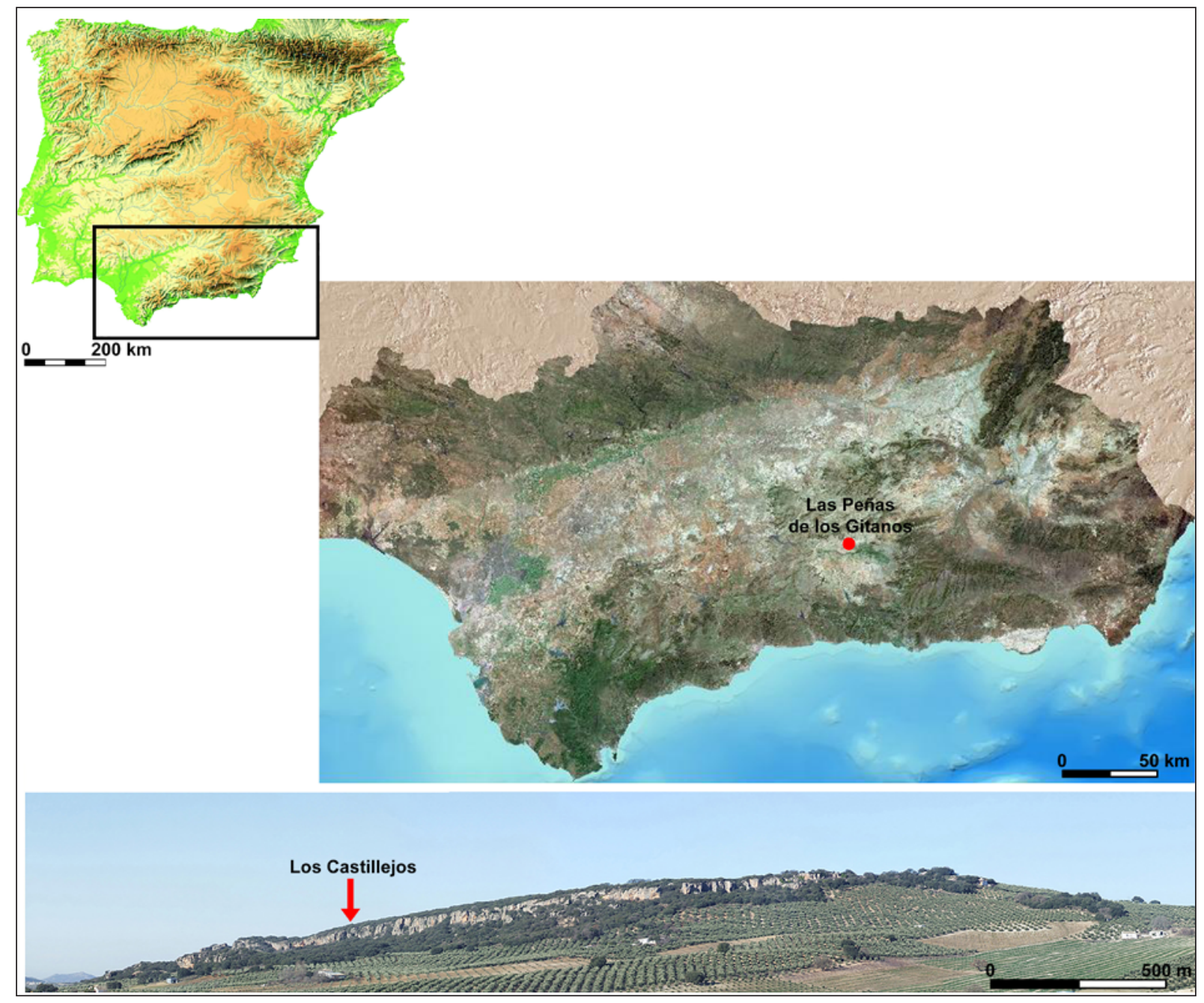

Figura 1. Panorámica del yacimiento de Los Castillejos en las Peñas de Los Gitanos en Montefrío (Granada) (Foto J. A. Afonso Marrero).

\section{INTRODUCCIÓN}

El poblado de Los Castillejos se encuentra en un macizo kárstico denominado Las Peñas de los Gitanos, situado en el municipio de Montefrío en la provincia de Granada, a unos $35 \mathrm{~km}$ al NO de la capital. Este sitio constituye un conjunto arqueológico (fig. 1) muy amplio con cuevas y pasillos, utilizados para hábitat y/o enterramiento, que son el resultado de la disolución kárstica de los afloramientos dolomíticos. El conjunto fue dado a conocer por primera vez en 1868 por M. de Góngora (1991). Más tarde M. Gómez-Moreno describió algunos sepulcros de la zona (Gómez-Moreno 1949). En 1926 su discípulo C. de Mergelina realizó excavaciones arqueológicas tanto en el poblado de Los Castillejos como en la necrópolis dolménica y en Cueva Negra, aunque las publicaciones solo aparecieron tras la Guerra Civil (Mergelina 1941-42; 1945-46). Los arqueólogos alemanes Georg y Vera Leisner visitaron la zona en los años treinta del siglo XX e incorporaron la necrópolis en su catálogo sobre las tumbas megalíticas del sur de la península ibérica (Leisner y Leisner 1943). M. Tarradell en 1946 volvió a excavar en el poblado de Los Castillejos alcanzando por primera vez los niveles de la Prehistoria Reciente, realizando también intervenciones en las cuevas vecinas (Tarradell 1952). En el marco del Congreso de Arqueología de Campo, auspiciado por la Comisaría General de Excavaciones Arqueológicas y celebrado en Granada en 1953, E. Van Giffen excavó un dolmen en el Hoyón de la Virgen (zona actualmente 
Tabla 1. Cronología del yacimiento de Los Castillejos en la Peña de los Gitanos en Montefrío (Granada).

\begin{tabular}{|l|l|c|c|c|}
\hline \multicolumn{2}{|c|}{ PERIODOS } & CRONOLOGÍA & FASES ESTRATIGRAFICAS \\
\hline Neolítico Antiguo & & I & $(5400-5000$ a.C. $)$ & $1,2,3,4 \mathrm{a}, 4 \mathrm{~b}, 5,6$ \\
\hline Neolítico Medio & & II & $(5000-4880$ a.C. $)$ & $7,8,9,10 \mathrm{a}, 10 \mathrm{~b}, 11 \mathrm{a}, 11 \mathrm{~b}$ \\
\hline \multirow{2}{*}{ Neolítico Reciente } & & & $(4880-4400$ a.C. $)$ & \\
\cline { 2 - 5 } & Neolítico Tardío & III & $(4400-3600$ a.C. $)$ & $12,13,14$ \\
\hline Cobre Antiguo & & IV & $(3600-3300$ a.C. $)$ & $15,16 \mathrm{a}$ \\
\hline \multirow{2}{*}{ Cobre Pleno } & & V & $(3300-3000$ a.C. $)$ & $16 \mathrm{~b}, 17$ \\
\hline \multirow{2}{*}{ Cobre Reciente } & Cobre Tardío & VII & $(2550-2300$ a.C. $)$ & 18,19 \\
\cline { 2 - 5 } & Cobre Final & VIII & $(2300-1900$ a.C. $)$ & $20,21,22$ \\
\hline Bronce Antiguo Inicial & & IX & $(1900-1800$ a.C. $)$ & $23 \mathrm{a}, 23 \mathrm{~b}, 23 \mathrm{c}$ \\
\hline
\end{tabular}

conocida como El Castellón), realizándose además una excavación limitada en el poblado de Los Castillejos, cuyos datos nunca llegaron a ser publicados. Las actuaciones más conocidas se realizaron en 1971 y 1974 por un equipo del Departamento de Prehistoria y Arqueología de la Universidad de Granada, dirigido por A. Arribas y F. Molina. En ese momento se volvieron a excavar algunos megalitos, se llevó a cabo una intervención en la Cueva de las Tontas y, sobre todo, se realizaron nuevos sondeos en el poblado que ofrecieron una secuencia estratigráfica que abarcaba desde momentos neolíticos hasta la Edad del Bronce (Arribas y Molina 1978; 1979). Será entre 1991 y 1994 cuando la Universidad de Granada realice nuevas intervenciones en el yacimiento prehistórico, presentándose a partir de ellas, con el apoyo de los resultados proporcionados por las dataciones de $\mathrm{C}^{14}$ y Termoluminiscencia, una ocupación prehistórica del área excavada (corte 1c/6) entre el 5400 (Neolítico Antiguo) y el 1800 cal a.C. aproximadamente, aunque con un hiato en los siglos centrales del V milenio a.C. (Ramos et al. 1997; Cámara et al. 2016; Molina et al. 2017) y ocupaciones posteriores de momentos más avanzados de la Edad del Bronce afectadas por la erosión pero documentadas en otras áreas como el corte 4a (Aguayo 1986; Cámara et al. 2016) (tab. 1).

\section{MATERIAL, MÉTODO Y OBJETIVOS}

En el presente trabajo se han estudiado todos los útiles y los adornos manufacturados en materias duras de animales vertebrados del poblado de Los Castillejos en las Peñas de los Gitanos (Montefrío, Granada, España). Nuestros objetivos son elaborar una clasificación tipológica de los artefactos, obtener información sobre el tipo de materia ósea utilizada, evaluar los procesos de trabajo, determinar las condiciones de uso y estimar la variabilidad en el tiempo de instrumentos y adornos.

Se han analizado 158 artefactos hallados durante las intervenciones arqueológicas realizadas entre 1991 y 1994, de los cuales 129 totalmente inéditos y 29 estudiados previamente (tab. 2) (Pau y Molina 2015; Pau 2015, 2016; Pau y Cámara 2018). Se ha añadido el resto de los materiales, manufacturados en la misma materia prima, recuperados en las excavaciones de 1946-47, 1971 y 1974 (Moreno 1982; Salvatierra 1982; Altamirano 2013a; 2013b; 2014a; 2014b; Pau y Molina 2015; Pau 2016).

Los artefactos hallados en las campañas de 1991 y 1994 han sido dibujados, fotografiados (cámara réflex digital Canon EOS 400D digital) y escaneados. Las imágenes se han recogido en láminas y se han tomado sus medidas con un calibre digital para incluirlas en una base de datos. Se ha realizado un análisis morfológico de los objetos que ha permitido proponer una clasificación tipológica (tab. 2) (siguiendo a Camps Fabrer et al. 1990; Uscatescu 1992; Pascual 1998; Maicas 2007; Bonnardin 2009; López 2011; Altamirano 2013a; Oliva 2015; Pau 2016). Se han dividido los artefactos en cinco categorías: útiles, adornos, ídolos, otros e indeterminados. Para el 


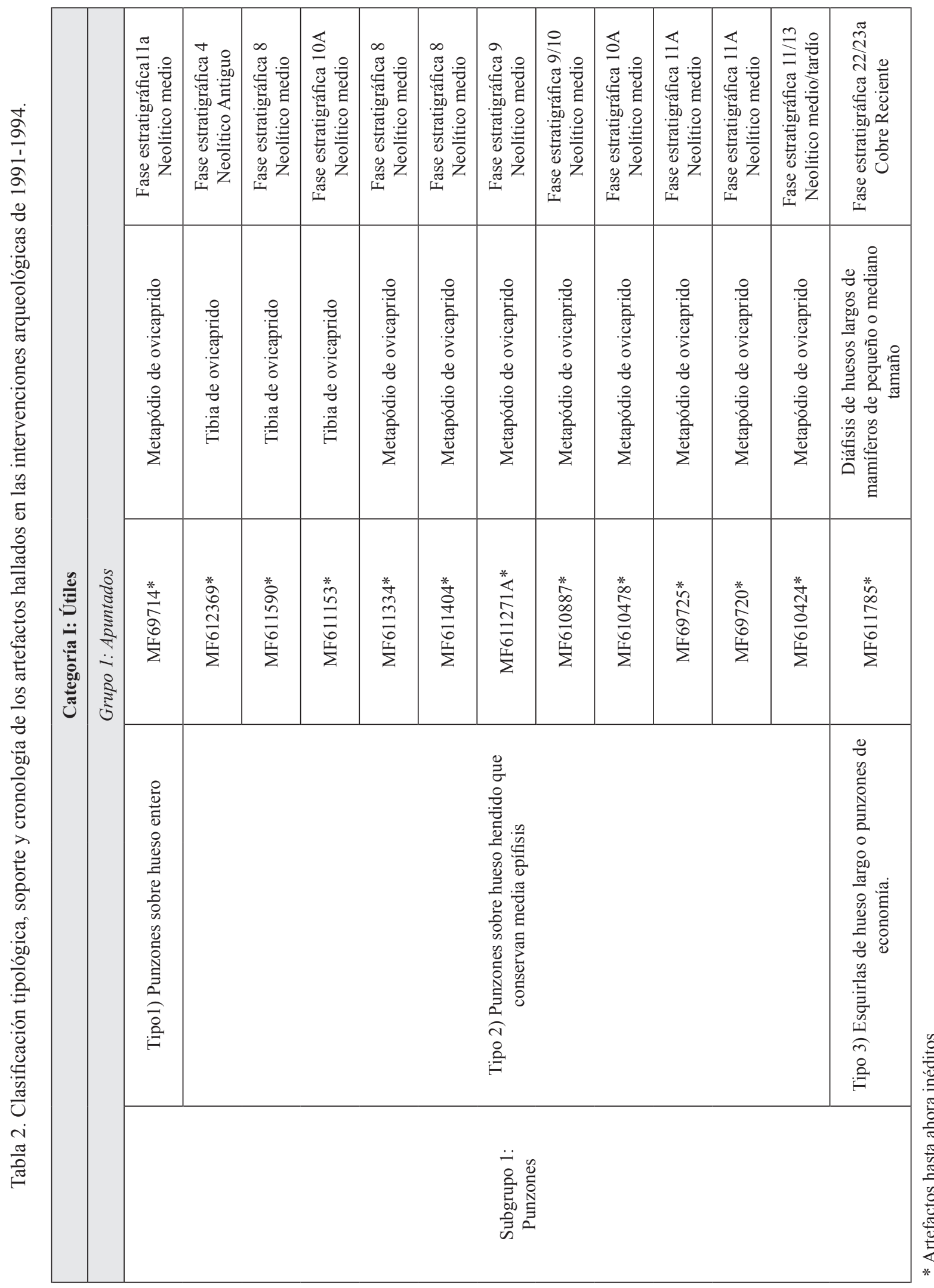




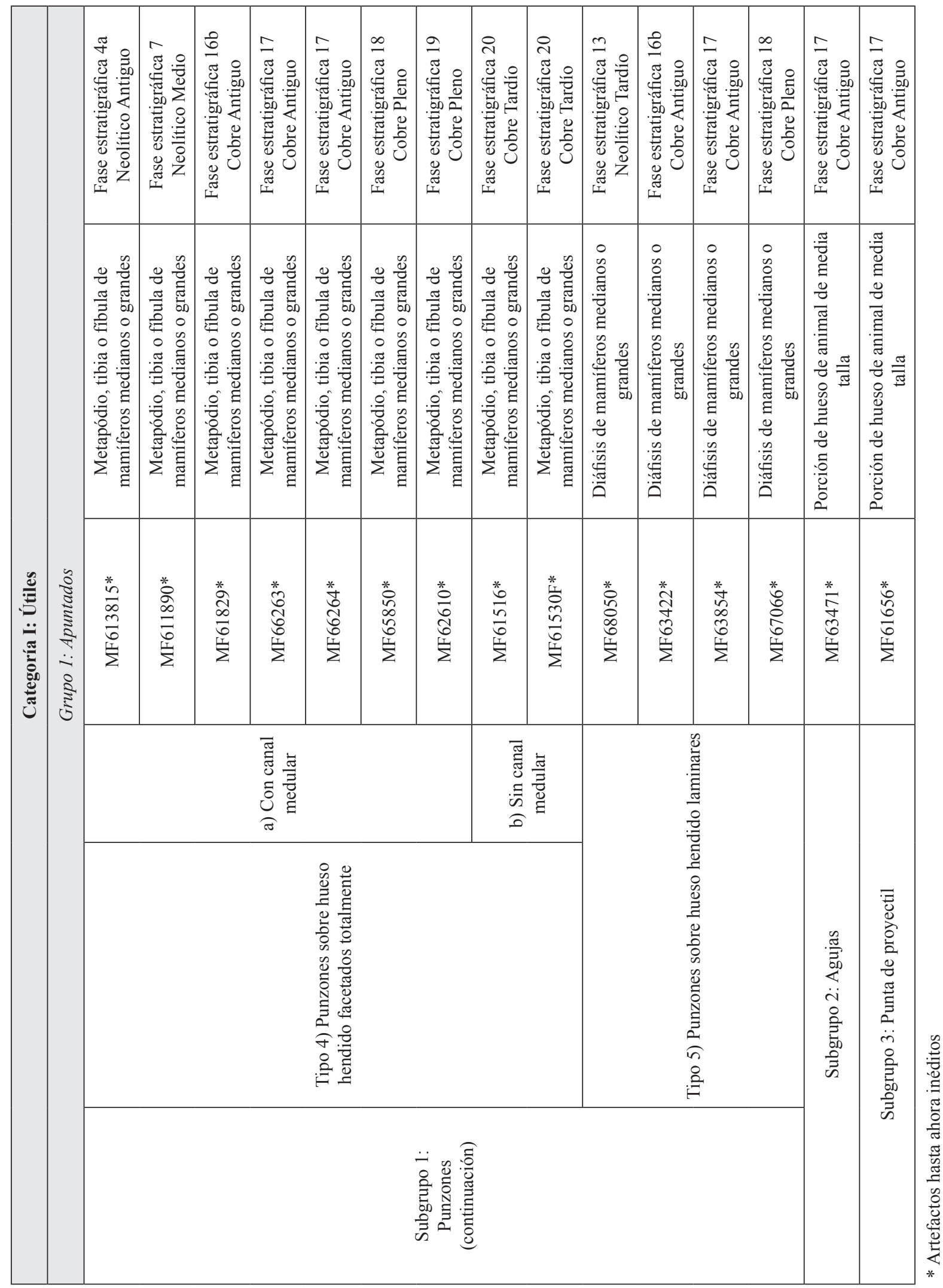




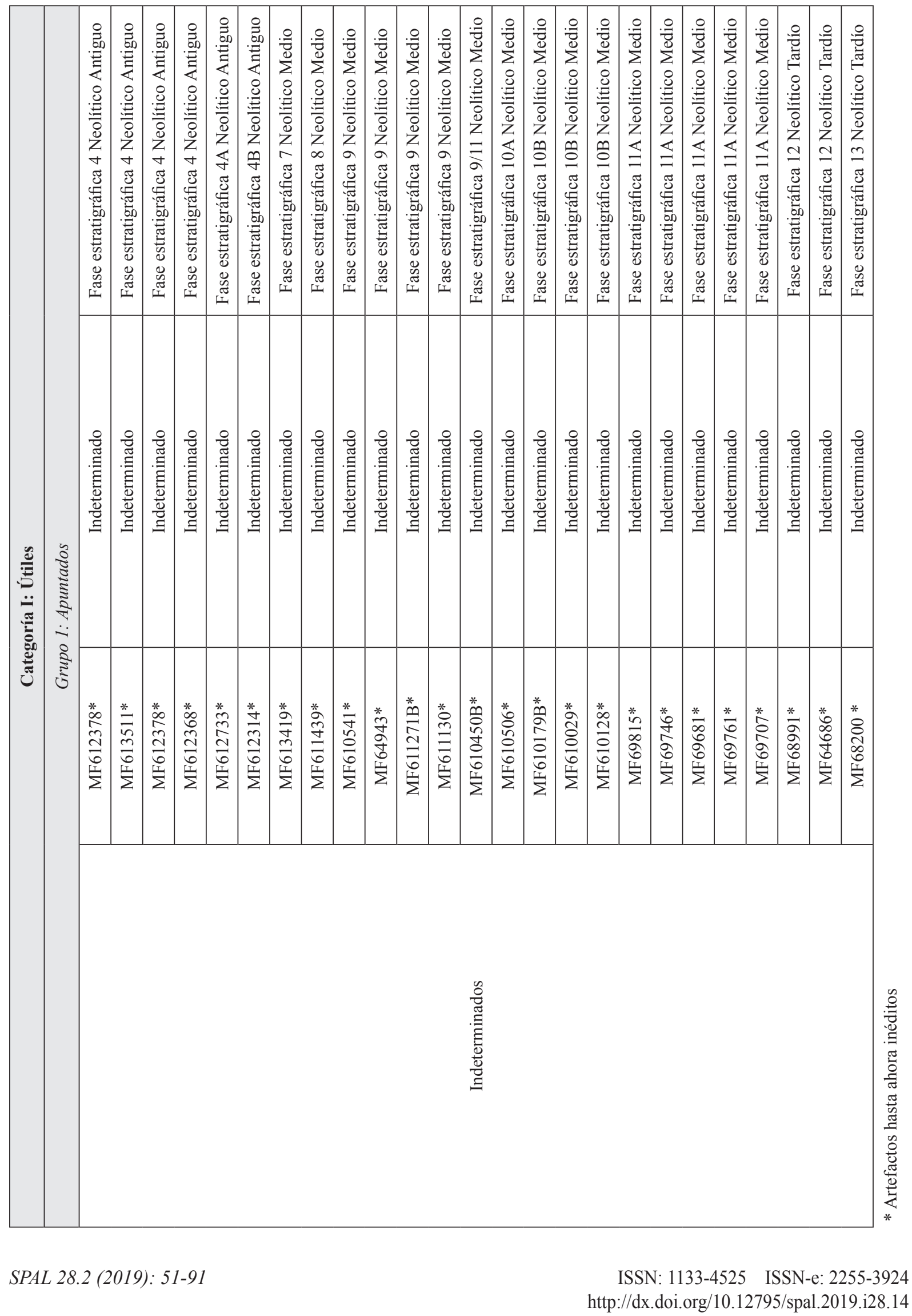




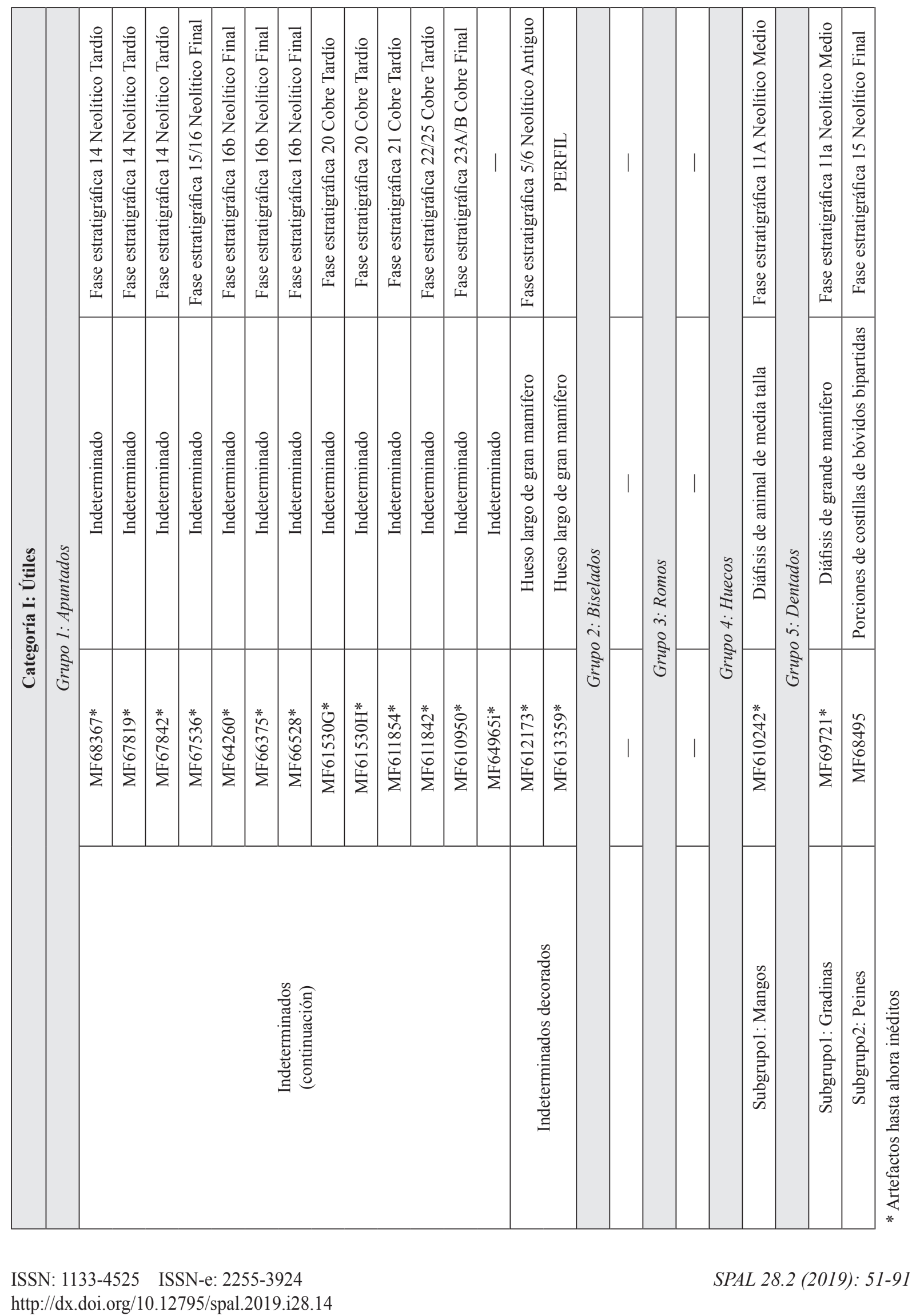




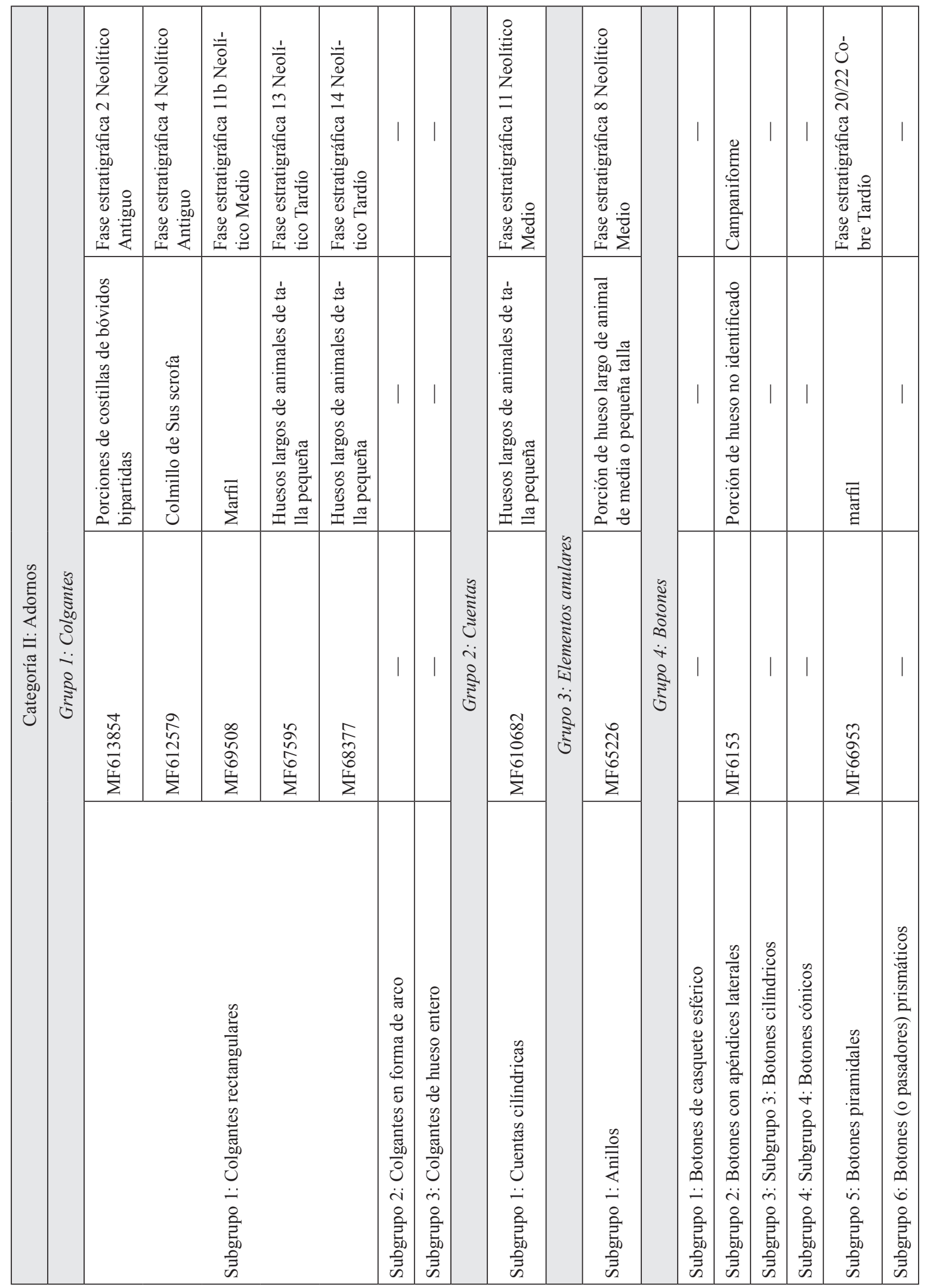




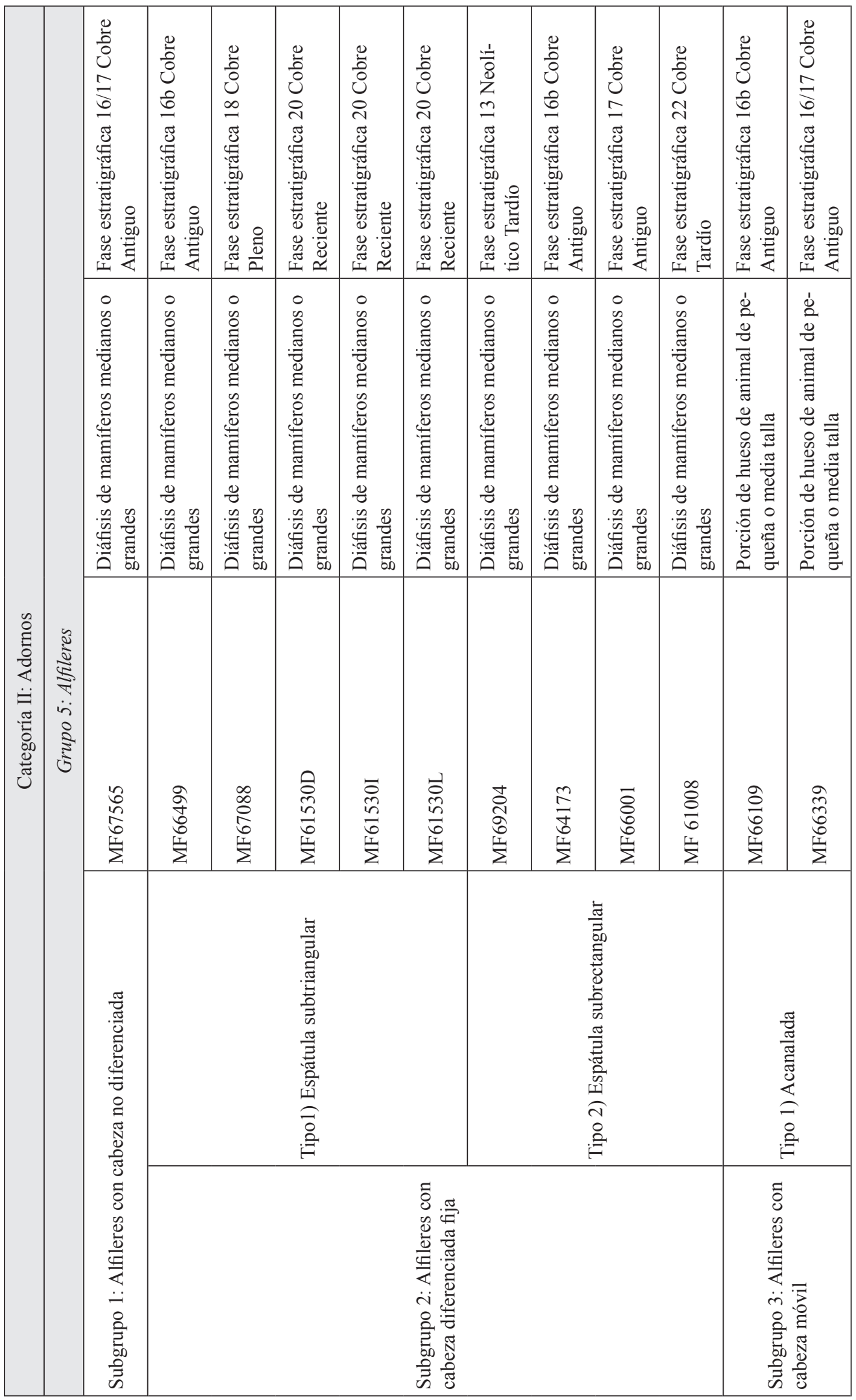




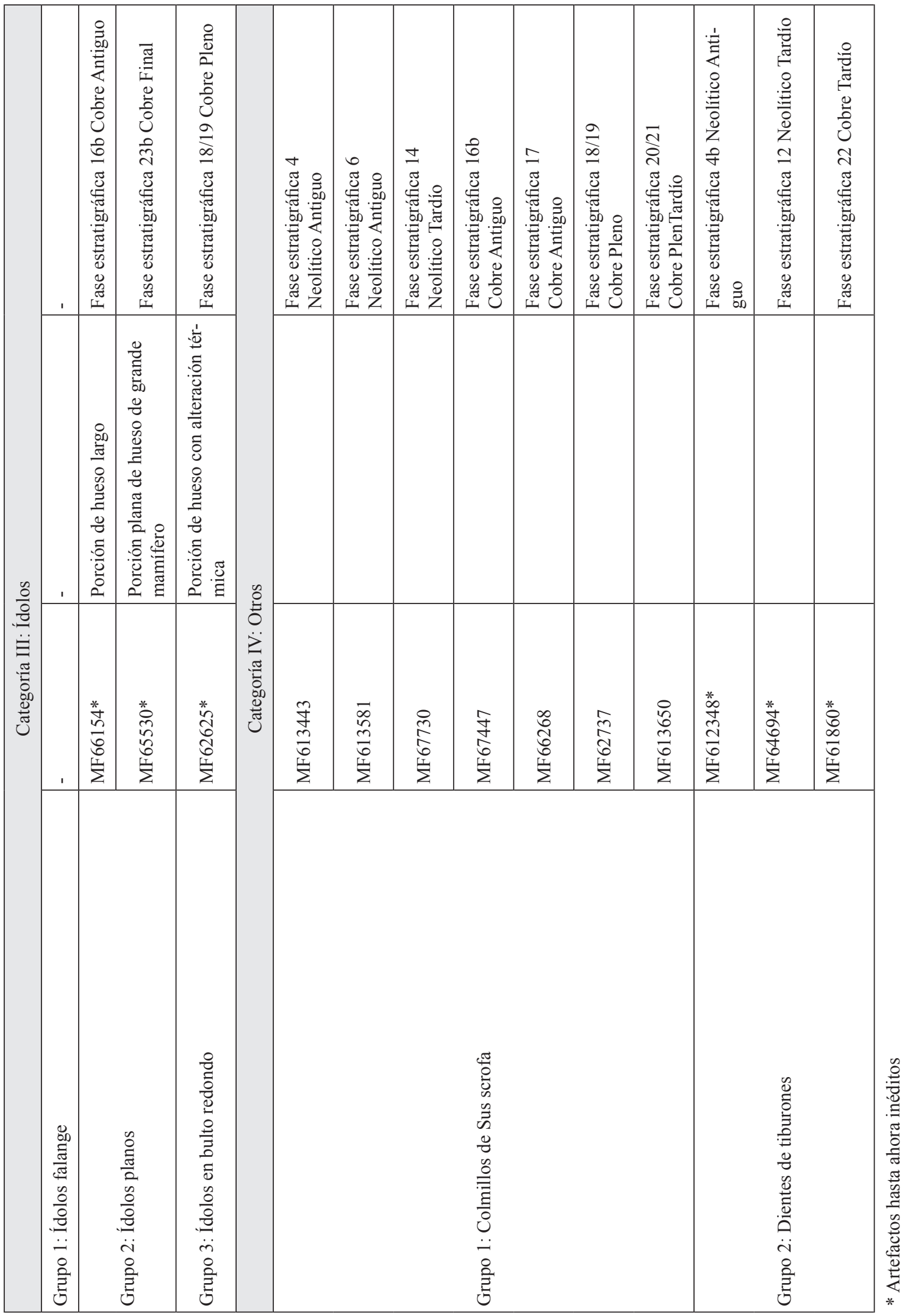


尊 䓪

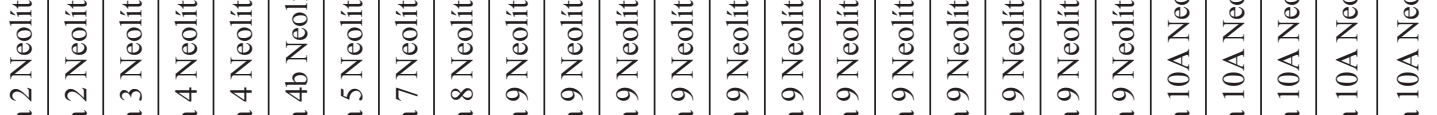

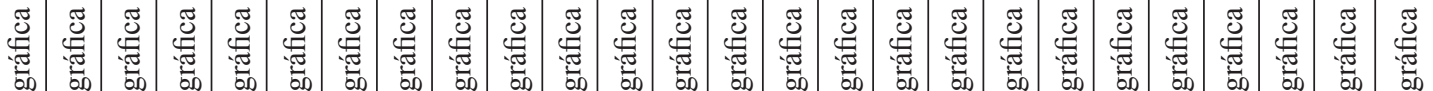

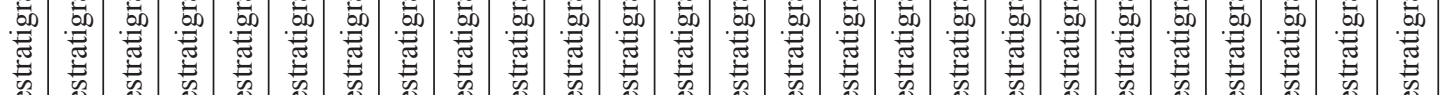

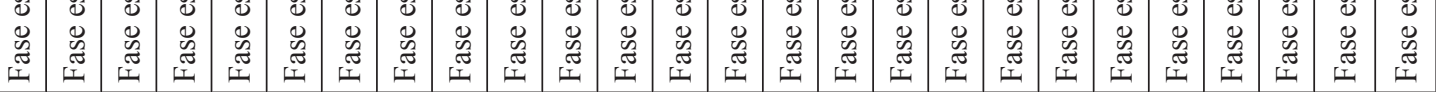

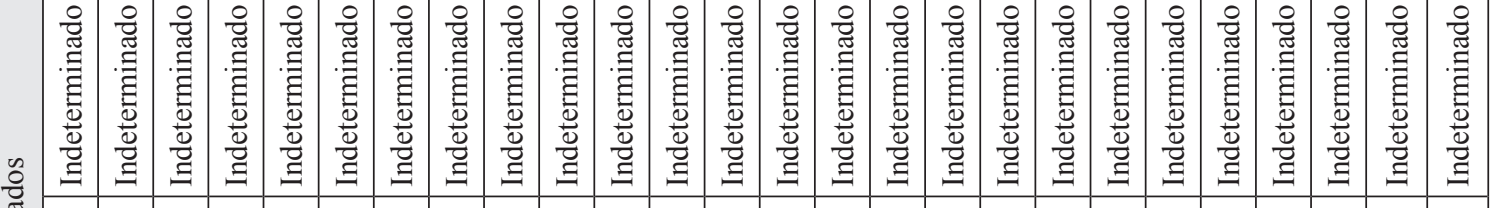




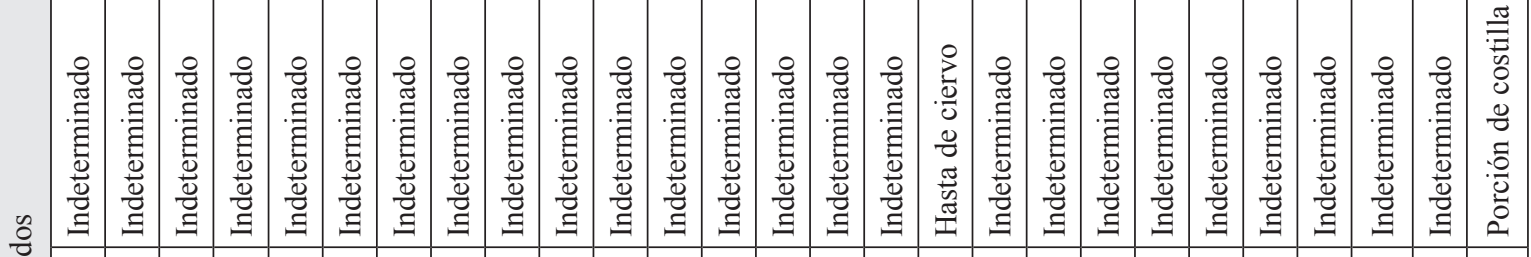

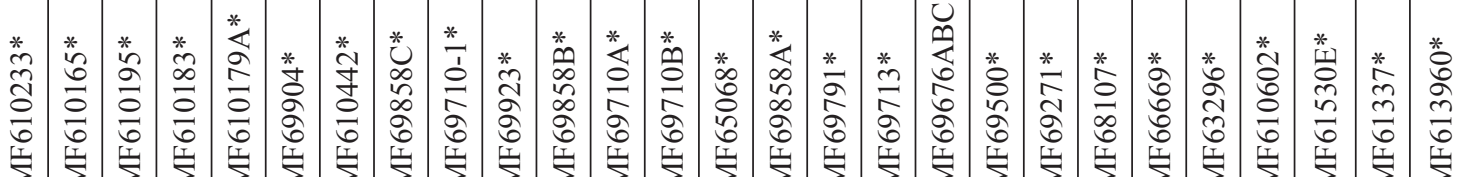

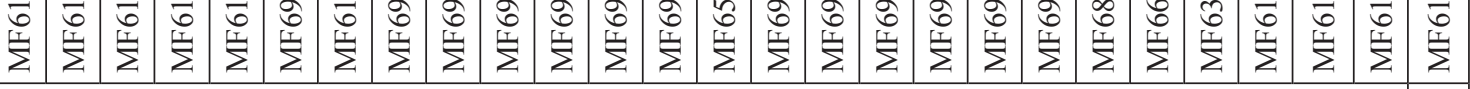


análisis de los útiles se ha tomado como criterio de diferenciación la forma del extremo activo, lo que nos ha permitido dividirlos en cinco grupos. Los grupos se han dividido ulteriormente en subgrupos según su función hipotética. Además, en el grupo 1 se distinguen tipos y subtipos según el grado de trasformación técnica del artefacto. Los adornos se han dividido siguiendo grupos tipológicos propuestos en otras clasificaciones tipológicas, a partir de criterios morfológicos, funcionales y métricos. Los subgrupos y los tipos se han distinguido teniendo en cuenta el grado de transformación y las características morfológicas. Los ídolos se han ordenado en tres grupos según su morfología general. En la categoría "otros" hemos incluido los dientes de tiburón y los colmillos de Sus scrofa. En la categoría de "indeterminados" tienen cabida los fragmentos de artefactos que no se han podido incorporar en las categorías anteriores. En cuanto a la nomenclatura utilizada en la descripción de los artefactos se sigue la terminología que viene siendo habitual en las publicaciones sobre industria ósea (entre otros Barge et al. 1991: 2; Pascual 1998: 20-21; Maicas 2007: 31-32), adaptándola a los artefactos en estudio. Se define como extremo o parte distal la parte activa y la proximal la opuesta, que en el caso de los colgantes presenta la perforación. Se define como cara inferior aquella que teóricamente sirve de apoyo al objeto, la interna del hueso, mientras se identifica como superior aquella que se muestra al observador externo. Los bordes derecho e izquierdo se definen, en esta línea, desde la perspectiva del observador. En los botones hablaremos de cara ventral para referirnos a la plana con perforación, y de dorsal para hacer mención a la opuesta. Pese a todo, en los casos de los artefactos que conserven partes identificables del hueso original se describirán en principio con la terminología osteológica.

Para la identificación de las materias primas se han realizado comparaciones con colecciones de hueso privadas y públicas. Finalmente, para llegar a definir la función de los elementos, se ha atendido a su distribución espacial y se ha utilizado el análisis traceológico mediante microscopio estereoscópico Leica EZ4 HD con cámara digital integrada y Microscopio Electrónico de barrido Ambiental (ESEM) FEI, Mod. Quanta 400, útiles también para la identificación de las técnicas de fabricación.

Solo los materiales de las campañas de los años 90 del siglo XX, objeto central del trabajo, han sido incluidos en tablas y en figuras.

\section{RESULTADOS}

\subsection{Estudio tipológico, análisis de la materia prima y cronología}

\subsubsection{Categoría I: Útiles}

\subsubsection{Grupo 1: Apuntados}

Constituyen este grupo los utensilios alargados con un extremo apuntado (fig. 2; tab. 2).

Subgrupo 1: Punzones

Son útiles alargados, con longitud inferior a $18 \mathrm{~cm}$, que podemos dividir en 5 tipos. El Tipo 1 incluye elementos confeccionados a partir de hueso entero y con la epífisis proximal o distal del hueso que conserva la forma natural. Los elementos del Tipo 2 están realizados a partir de hueso hendido que conserva media epífisis. El Tipo 3 está caracterizado por apuntados hendidos que denominamos "esquirlas de hueso largo", realizados sobre fragmentos irregulares de diáfisis de huesos largos de mamíferos de mediano o pequeño tamaño, que no presentan un acabado muy refinado. El tipo 4 está constituido por apuntados hendidos, facetados totalmente, con secciones cóncavo-convexa o plano-convexa y que pueden conservar evidencia del canal medular (4a) o no (4b). El tipo 5 comprende útiles obtenidos de huesos largos o costillas de mamíferos, de medias o grandes dimensiones, sección muy plana y delgada, cuerpo rectilíneo y talón con base recta o redondeada hasta alcanzar una morfología laminar.

En el yacimiento de Los Castillejos, durante la intervención arqueológica de la última década del siglo XX, se ha encontrado un único punzón del tipo 1 (MF69714), sin la punta, perteneciente al Neolítico Medio, fabricado sobre un metapodio entero de ovicáprido, que conserva la epífisis proximal del hueso entera. Por el contrario, en las campañas anteriores se localizaron numerosos elementos de este tipo, como testimonian M. Altamirano (2013a: $317-$ 320; 2014a: 25) y V. Salvatierra (1982). Se conservan dos punzones sobre tibia de ovicáprido con la epífisis proximal del hueso transformada. Además, hay tres artefactos (MF180, MF135, MF3455) sobre metapodio entero que conservan la epífisis distal del hueso, de los cuales MF180 pertenece al Cobre Pleno y MF135 al Cobre Tardío. En fíbula de suido, M. Altamirano (2013a: 319) habla de 13 artefactos que conservan la epífisis proximal del hueso y que se pueden situar entre el Neolítico Final/Cobre Antiguo 
(MF6088A) y el Bronce Antiguo (MF3272 y 3165). El mismo investigador señala cuatro apuntados más de este grupo, dos obtenidos de fíbulas de carnívoros o aves (MF2216, MF734), uno sobre costilla de mesomamífero (MF3610) y otro (MF692) sobre metapodio lateral de équido (Altamirano 2013a: 319, 320), que se fechan entre el Cobre Antiguo y el Cobre Tardío.

Las intervenciones de 1991-94 han traído a la luz 11 útiles del tipo 2. Tres punzones obtenidos de tibias (MF612369, MF611590, MF611153) pertenecen al periodo neolítico del yacimiento, el primero al Neolítico Antiguo, los últimos dos al Neolítico Medio. Ocho artefactos del tipo 2 se realizaron con metapodios de ovicáprido y todos pertenecen al Neolítico Medio (MF611334, MF611404, MF611271A, MF610887, MF610478, MF69725, MF69720, MF610424). Entre estos artefactos destaca el punzón MF611271A decorado con seis líneas paralelas, irregulares tanto en la profundidad de la incisión como en el trazo.

En las campañas anteriores se hallaron varios punzones de este tipo. Un ejemplar (MF8005) realizado a partir de medio metapodio de ovicáprido que conserva la epífisis distal del hueso (Bronce Antiguo) y tres útiles, MF6088B (Neolítico Final/Cobre Antiguo), MF692 y MF3632 (Cobre Tardío), que conservan la epífisis proximal del hueso.

En 1993 se halló el útil MF611785 del Cobre Reciente, adscrito al tipo 3 y manufacturado sobre diáfisis de hueso largo de mamífero de mediano o pequeño tamaño. En las anteriores intervenciones se recuperaron diez artefactos del mismo tipo, datados entre el Neolítico Final y el Cobre Pleno.

Entre los punzones facetados totalmente, del tipo $4 \mathrm{a}$, contamos con un total de siete útiles, procedentes de las intervenciones arqueológicas del final del siglo XX. Un elemento (MF613815) pertenece al Neolítico Antiguo, otro (MF611890) al Neolítico Medio, tres (MF61829, MF66263, MF66264) al Cobre Antiguo y dos al Cobre Pleno (MF65850, MF62610). De las campañas anteriores, M. Altamirano (2013a: 323-324) habla de 11 elementos que corresponden a nuestro tipo 4a que se pueden datar entre el Cobre Antiguo y el Cobre Tardío.

De los artefactos del tipo 4b se hallaron dos punzones en las campañas aquí estudiadas, el MF61516 y el MF61530F, del Cobre Tardío. En las campañas más antiguas M. Altamirano (2013a: 324) indica la existencia de cinco punzones, del mismo tipo, situados al menos del Cobre Antiguo al Pleno.
Los punzones del tipo 4 fueron manufacturados sobre metapodios, tibias o fíbulas de animales de media o gran talla.

Del tipo 5 se conservan 14 artefactos. Se cuenta con diez útiles (Altamirano 2013a: 326-327), manufacturados en costilla de mamífero, fechados entre el Cobre Antiguo y el Tardío (MF406), hallados en las excavaciones anteriores a los años 90 del siglo XX.

Además, se han estudiado cuatro artefactos de las intervenciones arqueológicas de 1991-1994 manufacturados en diáfisis de mamíferos medianos o grandes, uno (MF68050) del Neolítico Tardío, dos (MF63422 y MF63854) del Cobre Antiguo y el último (MF67066) del Cobre Pleno. Destaca el artefacto MF68050 por la presencia de un nervio central. Del tipo 5 entre el conjunto de materiales de las campañas anteriores encontramos tres elementos (MF2193, MF2147, MF2211) manufacturados en diáfisis de mamíferos medianos o grandes (Altamirano 2014a: 28-29), datados del Cobre Antiguo al Pleno.

\section{Subgrupo 2: Agujas}

Se definen como agujas, independientemente de su funcionalidad real, los apuntados con una perforación en la parte proximal y con los bordes del cuerpo que convergen hacia la punta.

En 1991 se halló la aguja MF63471, del Cobre Antiguo, que presenta una perforación bipolar de forma circular y sección triangular. No conserva la extremidad distal, aunque por su morfología pensamos pueda haber sido apuntada, mientras su extremidad proximal es recta. Ha sido manufacturada sobre un hueso largo de animal de media talla y conserva todavía el canal medular visible. Añadimos a este subgrupo dos agujas del Bronce Antiguo, una (MF3175) realizada utilizando un radio de carnívoro y otra (MF3225) en fíbula de suido que conserva los rasgos anatómicos naturales del hueso (Altamirano 2013a: 319; 2014a: 25).

\section{Subgrupo 3: Puntas de proyectil}

Son elementos alargados macizos con una extremidad apuntada y sección circular, oval o rectangular, con bordes convexos convergentes, con o sin aletas. Pueden mostrar un pedúnculo bien diferenciado o no. El ejemplar encontrado en 1991, MF61656, presenta sección oval y un pedúnculo marcado y se puede adscribir al Cobre Antiguo. Está manufacturado con una porción de hueso de animal de media talla. 


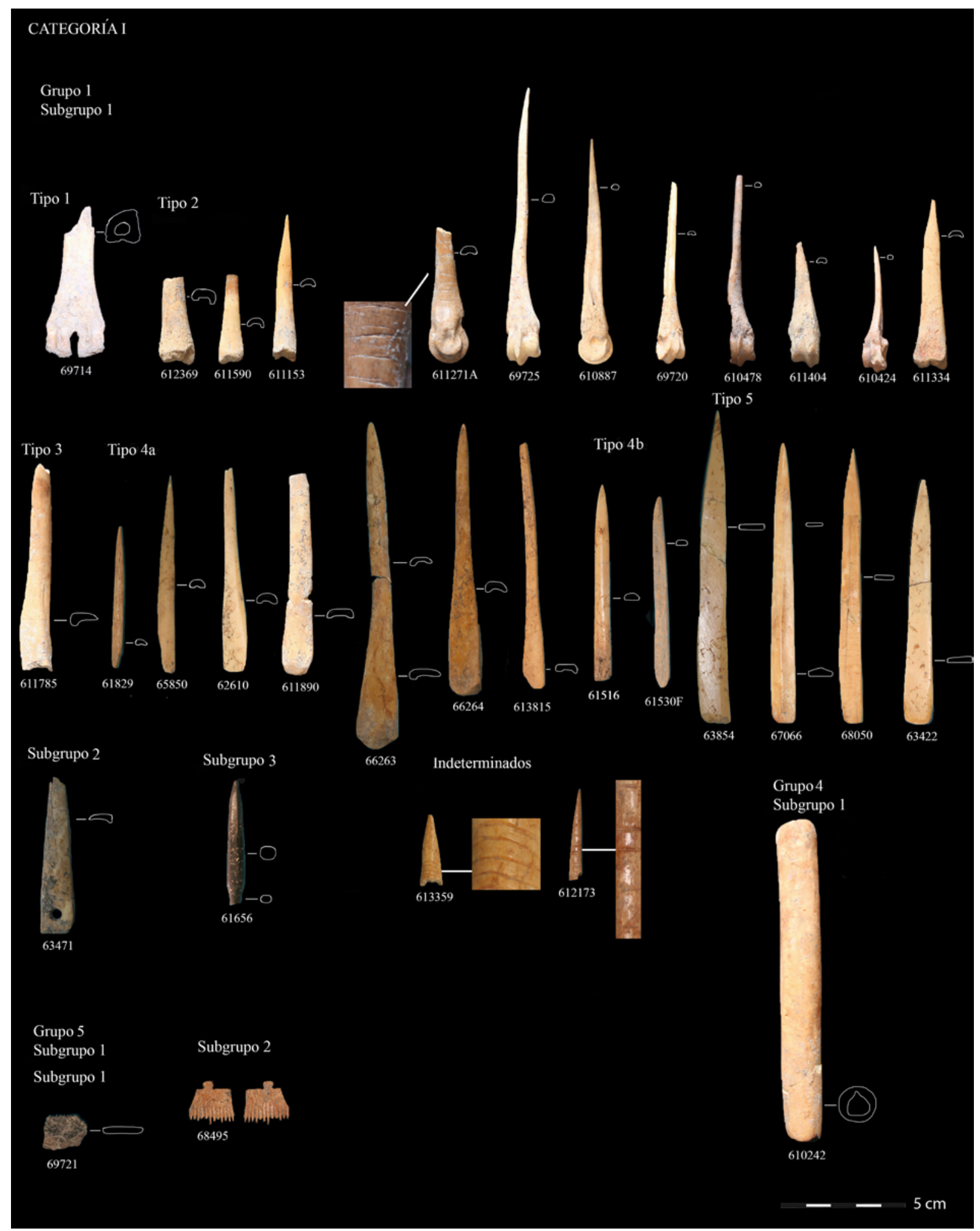

Figura 2. Artefactos de la categoría I. 
Apuntados indeterminados

Definimos como tales 40 extremos distales o medio distales apuntados que, por su estado de fragmentación, no podemos caracterizar de forma más precisa. Destacamos dos objetos por su decoración. El primer fragmento, MF612173, es la extremidad de un útil apuntado sobre hueso largo de gran mamífero, decorado con cinco líneas paralelas aunque no equidistantes. Se puede fechar en el Neolítico Antiguo. El segundo, MF613359, es probablemente la punta de un punzón sobre hueso largo de animal de gran talla y está decorado con cinco incisiones concéntricas en la zona conservada.

En las excavaciones de los años 1946-47 y 1971-74 se localizó un total de 12 fragmentos distales apuntados no determinables (Altamirano, 2013a: 332, 333). Se debe referir además un apuntado sobre asta de ciervo bipartido (candil), MF187 (Altamirano 2014a: 30), que podemos fechar en el Cobre Pleno.

\subsubsection{Grupo 2: Biselados}

En este grupo se han incluido los objetos que presentan la parte activa biselada.

Todos los útiles biselados se hallaron en las intervenciones arqueológicas anteriores a 1991. Dos útiles, MF6008c y MF3286, pueden ser definidos como cinceles. El primero, manufacturado en diáfisis de animal de gran tamaño, pertenece a un momento de transición entre el Neolítico Final y el Cobre Antiguo, mientras que el segundo, con doble bisel y obtenido de un metapodio de mamífero de gran tamaño, se puede fechar en el Cobre Final. Por otro lado, para el artefacto MF3090, en asta de ciervo, se ha propuesto una doble función, para cortar o incidir (en el lado del bisel), y como percutor (en el lado opuesto) (Altamirano 2013a: 320, 321, 341343; 2013b; 2014a: 27).

\subsubsection{Grupo 3: Romos}

Indicamos como útiles romos los que presentan la parte activa con los bordes redondeados.

En este grupo se ha incluido un útil, MF3627, encontrado en las campañas antiguas, obtenido de una porción de costilla de bóvido (Altamirano 2014a: 26) y fechado en el Cobre Tardío.

\subsubsection{Grupo 4: Artefactos huecos}

Definimos como artefactos huecos los útiles que presentan la parte activa hueca (fig. 2; tab. 2). Pueden tener formas y funciones diferentes, entre ellas la de haber sido utilizados para contener o conservar materiales variados.

\section{Subgrupo 1: Mangos}

Son elementos realizados a partir de diáfisis de huesos largos o cuernas y con un hueco en una o en las dos extremidades.

El artefacto MF610242, hallado en 1993, presenta forma cilíndrica y sección circular. Ha sido realizado sobre una diáfisis de animal de media talla seccionando los dos extremos y se adscribe al Neolítico Medio. En los años 70 del siglo XX se halló un mango manufacturado en asta de ciervo ahuecada casi en su mitad y con escoplo de cobre en su interior, adscrito al Cobre Antiguo (Altamirano 2013a: 332; Salvatierra 1982: 280).

\subsubsection{Grupo 5: Dentados}

Hemos incluido en este grupo artefactos (fig. 2; tab. 2) diferentes que presentan una característica común, la posesión de uno de sus bordes dentado.

\section{Subgrupo 1: Gradinas}

Se definen como tales útiles largos y estrechos que muestran generalmente sección oval y el extremo distal dentado. Los dientes son generalmente de forma triangular y cortos.

El objeto MF69721, hallado en 1993, puede ser un fragmento de gradina probablemente manufacturada a partir de la diáfisis de un gran mamífero y se puede fechar en el Neolítico Medio.

\section{Subgrupo 2: Peines}

Definimos como peines piezas muy delgadas que presentan en el extremo distal una serie de dientes y el extremo proximal rectilíneo o con un pequeño apéndice. Los dientes o púas son estrechos y alargados, de morfología subrectangular con el extremo activo puntiagudo o redondeado.

En el conjunto de material examinado se ha encontrado un peine (MF68495) del Neolítico Final, con forma subrectangular, un apéndice trapezoidal y 12 pequeños dientes incompletos, que se manufacturó trabajando una porción de costilla de bóvido bipartida. Este artefacto había sido clasificado como adorno en un 
trabajo anterior (Pau y Cámara 2018: 223), aunque, teniendo en cuenta su posible función, consideramos más oportuno considerarlo un útil.

En el conjunto de Las Peñas se han hallado otros cinco ejemplares de peines de mayores dimensiones. Dos fueron recuperados durante las intervenciones arqueológicas de 1971-74 y tres fueron hallados por M. Tarradell en el poblado y en Cueva Alta. Todos fueron manufacturados sobre porciones de costillas de bóvido bipartidas y han sido adscritos al Cobre Antiguo (Altamirano 2013a: 328; 2014a: 30-32; 2014b).

\subsubsection{Categoría II: Adornos}

\subsubsection{Grupo 1: Colgantes}

Se han definido como colgantes objetos (fig. 3; tab. 2) con una longitud siempre superior a su anchura y que presentan la perforación en uno de los extremos (Pau 2016: 618; Pau y Cámara 2018).

\section{Subgrupo 1: Colgantes rectangulares}

Son piezas que presentan una forma rectangular o subrectangular, con las aristas redondeadas o rectas, sección subrectangular u oval y perforación circular en uno de los extremos (Pau 2012a: 147-148; 2016: 649-651; Pau y Cámara 2018: 213).

En las excavaciones de los años 90 del siglo XX se halló un total de cinco adornos de este subgrupo. Al Neolítico Antiguo se adscriben dos colgantes. El primero, MF613854, está fracturado en uno de sus extremos donde se encuentra la perforación circular. Su contorno es muy irregular y fue manufacturado trabajando una porción de costilla de bóvido. El segundo, MF612579, está roto en sus dos extremos y se obtuvo de un colmillo de Sus scrofa, presentando todavía la forma curvilínea natural de la materia prima. De su agujero de sujeción se conserva solo una parte, aunque en origen tendría que presentar forma cónica y sección triangular. Al Neolítico Medio podemos adscribir el objeto MF69508, en marfil, que presenta los extremos y los bordes rectos con las esquinas redondeadas, una perforación situada en uno de los extremos, ligeramente descentrada con sección circular. A niveles del Neolítico Tardío corresponden dos adornos, obtenidos de huesos largos de animales de talla pequeña. El primero, MF67595, está roto en uno de los extremos, mientras que en el otro presenta un agujero de forma cilíndrica y sección circular. El segundo,
MF68377, muestra doble perforación, una completa cónica, y otra rota cilíndrica. Este artefacto conserva en la cara inferior todavía la oquedad natural del hueso (Pau 2015; Pau y Cámara 2018: 213).

\section{Subgrupo 2: Colgantes en forma de arco}

Incluimos aquí los adornos que presentan forma arqueada natural o artificial y un medio visible para poderlos suspender como orificios o muescas.

En las campañas de los años 70 del siglo XX se encontró un colgante, MF2224, en marfil, que presenta las caras planas con los bordes cóncavo-convexos, al que faltan las dos extremidades. Se documentan los restos de una perforación en la parte central de uno de los bordes, ovalada con la sección triangular. Además, muestra otra perforación cerca de los límites del fragmento conservado. Este objeto de adorno se adscribe al Cobre Tardío (Pau 2016: 642).

\section{Subgrupo 3: Colgante de hueso entero}

Se trata de colgantes obtenidos de pequeños huesos de animales de talla pequeña o mediana, escasamente modificados, implicando, en la mayoría de los casos, solo la creación de un medio de suspensión (Pau 2016: 637).

El colgante MF7009, encontrado en las excavaciones antiguas, conserva la forma natural del metacarpo de cerdo, aunque parece fracturado en una extremidad, y la única alteración morfológica es la perforación. El colgante presenta, de hecho, dos agujeros circulares cada uno en la parte central de cada una de sus caras. Cronológicamente se puede situar en el Cobre Final (Pau 2016: 637).

\subsubsection{Grupo 2: Cuentas}

Se han definido como cuentas los elementos (fig. 3; tab. 2) de pequeño tamaño que presentan una anchura superior o igual a su longitud y una perforación central, normalmente única, cuyo eje corresponde con el de rotación de la pieza (Pau 2016: 660).

\section{Subgrupo 1: Cuentas cilíndricas}

Son cuentas de morfología cilíndrica y sección circular. Pueden presentar una perforación central circular u oval en sentido longitudinal a su eje máximo o 
aprovechar el canal medular natural (Pau 2012a: 120; 2016: 681-684).

Podemos citar la cuenta MF610682, un pequeño adorno hallado en 1993, obtenida de hueso largo de animal de pequeña talla, atribuida al Neolítico Medio (Pau y Cámara 2018: 216), para la suspensión de la cual se utilizaría el hueco natural del hueso. Las campañas de excavación de los años 70 del siglo XX ofrecieron también un fragmento, poco más de la mitad, de una cuenta cilíndrica (MF. 858), obtenida seccionando un hueso largo de un animal de media talla. No presenta perforación por lo que se utilizaría, para su sujeción, el hueco natural del hueso. Puede datarse en el Cobre Pleno (Pau 2016: 683).

\subsubsection{Grupo 3: Elementos anulares}

Son piezas (fig. 3; tab. 2) con sección circular, planoconvexa o rectangular y una gran abertura central (Pau 2016: 701).

\section{Subgrupo 1: Anillos}

Son elementos que presentan el diámetro exterior mayor que su espesor, y están dotados de una perforación interior con diámetro entre los 0,9 y $2,5 \mathrm{~cm}$. Pueden tener la anchura, el espesor y la sección del perímetro exterior regular o no (Pascual 1998: 152).

El elemento estudiado (MF65226) pertenece al Neolítico Medio y se fabricó a partir de una porción de hueso largo de animal de media o pequeña talla. Se puede considerar como elemento anular de tipo abultado (Pascual 1998: 154), con forma oval y cuerpo cóncavo-convexo, ya que de hecho conserva la forma natural del hueso con el que fue manufacturado. El perímetro exterior muestra una sección plana de diferente espesor y una zona con mayor anchura de forma subrectangular con los vértices redondeados (Pau y Cámara 2018: 216).

\subsubsection{Grupo 4: Botones}

En este grupo hemos incluido los objetos (fig. 3; tab. 2) provistos de perforación en "V" (convergente al interior de la pieza) que, por su forma y sus dimensiones, vienen generalmente identificados como botones (Pau 2016: 704).

Subgrupo 1: Botones de casquete esférico

Son pequeños elementos con sección plano-convexa y cara ventral plana (circular o elíptica) y dorsal curvilínea
(Pau 2016: 704-708). La perforación se encuentra en la cara ventral (Pascual 1998: 167). Han sido divididos en dos tipos según su espesor, normal (tipo 1) (desde $1 \mathrm{~cm}$ ) y aplanado (tipo 2) (menos de $1 \mathrm{~cm}$ ).

El único botón (MF10019) del tipo 1 se encontró en las intervenciones de los años 70 del siglo $\mathrm{XX}$, roto en dos partes. Realizado en marfil, presenta la cara plana de forma elíptica y una sección plano-convexa, con siete orificios, de los cuales seis son funcionales y tendrían que estar unidos (de dos en dos) en "V", mientras que el último es un simple intento de perforación. Los dos orificios ubicados en la parte central, perpendiculares al eje mayor, serían los primeros que se hicieron y se utilizaron hasta que se rompieron en la zona de unión. Para poder volver a utilizar la pieza fueron creadas nuevas perforaciones. Este adorno pertenece al inicio del Cobre Tardío (Pau y Molina 2015: 96-99, 106; Pau 2016: 708).

En la excavación de M. Tarradell se encontró un adorno (MF3217) en marfil del tipo 2 que presenta la cara ventral ligeramente ovalada y el perfil plano-convexo. Muestra dos agujeros ovales en la cara plana que se encuentran en " $\mathrm{V}$ " pero rompiendo la superficie dorsal y dejando en ella un agujero oval. Es posible que se calculase mal la profundidad de la perforación, no considerando el reducido espesor de la pieza. Se puede adscribir al Cobre Tardío (Pau y Molina 2015: 96-99, 106; Pau 2016: 708).

\section{Subgrupo 2: Botones con apéndices laterales}

Presentan cuerpo central circular, elíptico, cuadrangular o romboidal y dos apéndices laterales, cuadrangulares, rectangulares, triangulares o trapezoidales, que pueden estar apenas esbozados o bien delineados (Pau 2012a: 163; Pau 2012b: 69).

El adorno MF6153 fue hallado durante las intervenciones arqueológicas de 1991-94 y está manufacturado en hueso, aunque su alto grado de facetado y su estado de conservación impiden su identificación taxonómica y anatómica. Presenta el cuerpo elíptico con sección plano-convexa, dos apéndices de forma trapezoidal con sección plano-convexa, y muestra en la cara ventral la perforación en "V". Aunque localizado en los niveles alterados por los furtivos, sus características lo definen como un adorno típico del periodo Campaniforme (Pau y Molina 2015: 100-101, 106; Pau 2016: 716).

El segundo artefacto (MF3203), hallado en 1947, manufacturado sobre asta de ciervo (Altamirano 2013a: 337), 
presenta el cuerpo ligeramente ovalado, sección planoconvexa y dos apéndices de forma trapezoidal de sección plano-convexa. En la cara plana muestra dos agujeros ovales que se encuentran en "V" y se identifica en el dorso un pequeño agujero no intencional. El adorno se adscribe al Cobre Tardío (Pau Molina 2015: 100-101, 106; Pau 2016: 716).

\section{Subgrupo 3: Botones cilíndricos}

Presentan la forma de un cilindro, con las caras ventral y dorsal convexas y las laterales rectas y la sección lateral circular o ligeramente oval. Normalmente presentan la perforación en "V" en la parte central de la cara ventral (Pau 2016: 718-719).

El botón MF3218, procedente de las excavaciones de M. Tarradell, en marfil, muestra sección lateral oval $\mathrm{y}$ dos orificios de forma oval que se unen en "V". Como los anteriores se adscribe al Cobre Tardío (Pau Molina 2015: 102-106; Pau 2016: 718).

\section{Subgrupo 4: Botones cónicos}

Presentan la base plana de forma circular u oval, la cara dorsal de forma cónica y la sección de forma triangular (Pau 2016: 719-721).

En Los Castillejos se hallaron dos botones en marfil durante las intervenciones de los años 70 del siglo XX. El primer elemento, MF2260, presenta base plana de forma circular irregular y sección triangular y muestra en la parte central de la base dos agujeros de forma oval que se encuentran en "V". Este adorno pertenece al Cobre Tardío Inicial (Pau Molina 2015: 102-103, 106; Pau 2016: 720-721). El segundo elemento, MF22, de mayor tamaño, presenta la base plana de forma oval, sección triangular y un total de tres orificios. El primer agujero, de forma oval en el centro de la base, seguramente en origen consistía en dos orificios de forma oval unidos en "V" que por el uso prolongado se fracturarían en el punto de unión. Las otras dos perforaciones, ovales y ubicadas casi en los bordes de la cara ventral, se encuentran en "V" en el interior de la perforación originaria y serían realizados una vez que la primera perforación quedó inutilizada. Este adorno MF22 puede ser datado en el Cobre Tardío (Pau y Molina 2015: 102-103, 106; Pau 2016: 719-720).

Subgrupo 5: Botones piramidales

Presentan una base plana de forma cuadrada o rectangular, la parte dorsal formada por cuatro superficies planas triangulares convergentes y que presentan sección triangular (Pascual 1998: 167).

El botón piramidal MF66953, encontrado en 1992, ha sido manufacturado en marfil, presenta la base rectangular y sección triangular. En el centro muestra un único agujero oval, aunque probablemente en origen debieron ser dos unidos en "V" que se fracturaron en el punto de unión, dejándolo aparentemente inutilizable. Es un adorno del Cobre Tardío (Pau Molina 2015: 103104, 106; Pau 2016: 722).

Entre los botones localizados en las excavaciones de los años 70 del siglo XX, MF111, del Cobre Tardío, en marfil, alterado térmicamente, presenta la base rectangular, sección triangular y en la cara inferior dos agujeros de forma oval que se unen en "V". Se observa la ruptura del punto de unión, que, como ya había indicado M. Altamirano (2013a), es reciente. El botón MF2002 también en marfil, del Cobre Final, presenta base plana rectangular, sección rectangular y perforación en "V", fracturada en la parte de unión de los dos orificios (Pau y Molina 2015: 103-104, 106; Pau 2016: 722-725).

\section{Subgrupo 6: Botones prismáticos.}

Durante las intervenciones de 1971 y 1974 se halló un botón prismático triangular (MF1014). Los botones prismáticos triangulares son elementos que tienen la cara ventral de forma rectangular mientras la dorsal está formada por dos planos rectangulares y dos triangulares que convergen (Uscatescu 1992: 38; Pascual 1998: 167). De este adorno se ha perdido casi la mitad de su cuerpo y conserva solo uno de los dos orificios de sujeción que originariamente tendrían que haber estado unidos en "V" (Pau y Molina 2015: 104-106; Pau 2016: 726). Fue realizado a partir de una porción en forma de prisma cortada de una rodaja de marfil, como demostrarían las líneas concéntricas en las bases (Altamirano 2013a: 336). Lo que destaca es su decoración de tipo inciso lineal y presente en el plano rectangular del dorso y en la parte superior del botón. Son visibles dos motivos, el primero está formado por seis líneas paralelas oblicuas y por dos líneas paralelas rectas, continuando estas últimas para formar una especie de espiga con dos grupos de cuatro y cinco líneas paralelas oblicuas. El artefacto se adscribe al Bronce Antiguo (Pau y Molina 2015: 104-106; Pau 2016: 729).

\subsubsection{Grupo 5: Alfileres}

Incluimos aquí los elementos en hueso pulido en forma de varilla, con sección circular, cuadrangular o rectangular 
y una de las extremidades puntiagudas (fig. 3; tab. 2). Los alfileres no poseen ni perforación ni muescas, siendo su fijación directa (Pau 2016: 731-737).

Subgrupo 1: Alfileres con una extremidad puntiaguda y cabeza no diferenciada.

Los objetos de este subgrupo son varillas muy delgadas que presentan sección cilíndrica, cuadrangular o rectangular y el mismo espesor en toda su longitud, siendo su característica principal que su cabeza no se diferencia del cuerpo.

Hemos estudiado solo una porción de alfiler (MF67565) de este subgrupo, hallada en 1992, aunque no descartamos la posibilidad que tuviera, en origen, una cabeza diferenciada del cuerpo, fija o móvil. Fue fabricado trasformando la diáfisis de un animal mediano o grande y se adscribe al Cobre Antiguo.

\section{Subgrupo 2: Alfileres con cabeza diferenciada fija}

Son alfileres con la parte activa apuntada y la parte proximal netamente destacada del cuerpo. Se dividen en dos tipos según la forma de la cabeza, en forma de espátula subtriangular en el 1 y subrectangular en el 2 (Pascual 1998: 111, 1129). Todos los artefactos estudiados se habían obtenido trabajando diáfisis de mamíferos medianos o grandes.

Del Tipo 1 contamos con un alfiler entero y cuatro fragmentos que conservan la cabeza y parte del cuerpo, hallados en las campañas arqueológicas de 1991-1994. El adorno completo MF66499 es del Cobre Antiguo, un fragmento, MF67088, del Cobre Pleno, y los otros tres (MF61530D, MF61530I, MF61530L) del Cobre Reciente.

En las campañas antiguas se habla de siete artefactos, dos completos y cinco rotos (Altamirano 2013a: 324, 2014a: 29; Pau 2016: 734-736), que se datan entre el Cobre Tardío (Pau 2016: 734) y el Bronce Antiguo.

Del tipo 2 contamos con cuatro artefactos hallados en las intervenciones de los años 90 del siglo XX: uno, MF69204, del Neolítico Tardío, dos del Cobre Antiguo (MF64173 y MF66001) (Pau y Cámara 2018: 222) y otro, MF61008, del Cobre Tardío.

\section{Subgrupo 3: Alfileres con cabeza móvil}

Son artefactos conformados por dos partes distintas: un cuerpo, generalmente de sección circular u oval y una cabeza independiente, perforada para poderla insertar en el cuerpo (Pascual 1998: 111; Pau 2016: 736).

En 1992 se encontraron dos cabezas decoradas del Tipo 1 (con cabeza móvil segmentada o acanalada). La primera (MF66109) presenta acanaladuras suaves paralelas y concéntricas, la segunda (MF66339) acanaladuras más profundas y una decoración en "V" en el borde. Los dos elementos, obtenidos de porciones de huesos de animales de pequeña o media talla, se pueden datar en el Cobre Antiguo (Pau y Cámara 2018: 222).

\subsubsection{Categoría III: Ídolos}

\subsubsection{Grupo1: Ídolos falanges}

Los ídolos falanges son ídolos antropomorfos realizados sobre falanges de animales (Maicas 2007: 115).

Un ídolo (MF1074) de este grupo, manufacturado sobre una falange de ciervo, fue localizado en las antiguas excavaciones y se adscribe al Cobre Reciente (Altamirano 2014a: 35).

\subsubsection{Grupo 2: Ídolos planos}

Se definen como ídolos planos figuraciones esquemáticas que se manufacturaban sobre soportes planos mientras con el uso de escotaduras se definían algunas partes en el intento de representar una silueta humana (Pascual 1998: 184).

En las intervenciones arqueológicas de la última década del siglo XX se hallaron dos ídolos planos (fig. 3; tab. 2). El primero, MF65530, del Cobre Final, es una porción plana de hueso de gran mamífero, con dos escotaduras enfrentadas y situadas en la parte central del objeto. El segundo ídolo, MF66154, fechado en el Cobre Antiguo, es una varilla obtenida de un hueso largo de un mamífero de gran talla, con dos pares de escotaduras que dividen el objeto en tres partes.

En las campañas anteriores se descubrieron dos ídolos de este grupo, obtenidos de huesos de grandes mamíferos, ambos con un estrechamiento en el cuerpo (Altamirano 2013a: 338). Uno (MF2312) es del Cobre Antiguo y otro (MF133) del Cobre Tardío.

\subsubsection{Grupo 3: ídolos en bulto redondo}

Son pequeños ídolos antropomorfos (tab. 2) con la cabeza bien delineada y el cuerpo estilizado de forma cilíndrica. El único elemento estudiado, MF62625 (fig. 3), hallado en 1991, ha sufrido una fuerte 
alteración térmica que lo ha ennegrecido y se adscribe al Cobre Pleno.

\subsubsection{Categoría IV: Otros}

En esta categoría insertamos colmillos y dientes de animales que no presentan evidencia de sistemas de sujeción (fig. 3; tab. 2).

\subsubsection{Grupo 1: Colmillos de suido}

En la intervención arqueológica de la última década del siglo XX se hallaron siete fragmentos de colmillos de suido sin ningún tipo de sujeción. Dos (MF613443, MF613581) son del Neolítico Antiguo, uno (MF67730) del Neolítico Tardío, dos (MF67447, MF66268) del Cobre Antiguo, uno del Cobre Pleno (MF62737), y uno del Cobre Tardío (MF613650).

En las campañas anteriores se recuperó un colmillo de Sus scrofa con las mismas características (MF743) (Altamirano, 2014a: 32-33).

\subsubsection{Grupo 2: Dientes de tiburones}

En este grupo insertamos un conjunto de fósiles, dientes de tiburones Isurus sp., sin modificaciones antrópicas.

En las intervenciones de 1991-1994, se encontraron tres artefactos de este tipo, uno entero y dos fracturados (fig. 3, tab. 2), uno (MF612348) del Neolítico Antiguo, otro (MF64694) del Neolítico Tardío y el último (MF61860) del Cobre Tardío.

En las excavaciones anteriores se hallaron dos dientes fracturados, sin las raíces (Altamirano 2014a: 35), uno, MF186, del Cobre Pleno y otro, MF3280, del Bronce Antiguo.

\subsubsection{Indeterminados}

Definimos como indeterminados 53 fragmentos de objetos que no podemos asignar con seguridad a ninguna de las categorías previas (tab. 2).

En primer lugar, destacamos el artefacto MF69713 manufacturado en cuerna de ciervo. También podemos referir una porción de costilla de bóvido hendida, MF613960, del Neolítico Antiguo (fig. 3), que podría ser un punzón laminar o un colgante sobre costilla y que está decorada con tres incisiones paralelas y equidistantes.
En las excavaciones de los años 1946-47 y 1971-74 se encontraron también dos fragmentos mediales manufacturados sobre hueso largo de grandes mamíferos (Altamirano 2013a: 332, 333).

\subsection{Contextualización espacial y cronológica}

Aunque, a la hora de describir el material, hemos hecho referencia al periodo cultural al que se atribuyen los diferentes elementos según su posición estratigráfica, en el caso de los objetos recuperados en las campañas arqueológicas de 1991-94 podemos ser más precisos, tanto en lo que se refiere a la fase estratigráfica de referencia (tab. 2) con su cronología, siguiendo las dataciones radiocarbónicas y de termoluminiscencia disponibles (Cámara et al. 2016; Molina et al. 2017), como en lo que respecta a las características de los espacios en los que los objetos fueron depuestos. Una síntesis de estos datos puede ayudar a atribuir funciones a determinados artefactos e incluso a evaluar posibles formas de deposición que pueden haber afectado a su conservación. La exposición seguirá el mismo orden de la clasificación tipológica, pero realizaremos referencias cruzadas cuando exista una cierta relación espacial entre los útiles para facilitar la comprensión de las afirmaciones que se mantendrán posteriormente en la discusión y las conclusiones.

De los punzones del tipo 1 solo contamos con un ejemplar procedente de las excavaciones de los años 90 del siglo XX, localizado en un estrato datado a fines del Neolítico Medio (fase estratigráfica 11a), a inicios del V milenio a.C., y se sitúa dentro del área de producción caracterizada (Cámara et al. 2016) por las estructuras de combustión, en contextos de desecho cubiertos por el derrumbe.

También los punzones del tipo 2 procedentes de las excavaciones de fines del siglo XX sólo se documentan en niveles del Neolítico Medio, a excepción del instrumento MF612369 del Neolítico Antiguo (fase estratigráfica 4). Particularmente los punzones de este tipo se hacen frecuentes desde la fase 10a, en momentos datados en los primeros siglos del V milenio a.C., y se constatan en el interior del área de producción caracterizada por las estructuras de combustión ya referida, en contextos de ocupación y derrumbe, pero también en algunos casos formando parte de los rellenos de las estructuras (MF611590) e incluso aparecen en el barro usado para construirlas por lo que deben ser ligeramente más antiguos de la propia estructura en que se incluyen (MF611153, MF611271A, MF610478). 
El único punzón del tipo 3 de estas campañas se localizó en contextos no bien definidos al interior de la fortificación que cierra el área habitada en Los Castillejos, al menos desde el Calcolítico Reciente. Posiblemente el ejemplar se situara dentro de una vivienda pero fue localizado al realizar las zanjas de cimentación de la plataforma de acceso actual, no pudiéndose asegurar que esos contextos inferiores no excavados arqueológicamente tuvieran la misma organización de los excavados en el área.

Los punzones del tipo 4a ya se constatan en el Neolítico Antiguo y principios del Medio, desde fines del VI milenio a.C. (fases 4a y 7), cerca de los hogares-hornos que caracterizan la zona de producción especializada excavada (Molina et al. 2016) (MF613815, MF611890). Sin embargo, este tipo 4a de punzones facetados parece más abundante en la transición al Calcolítico, constatándose siempre en niveles de ocupación, cubiertos por el derrumbe de los techos a menudo incendiados, adscritos al Cobre Antiguo y Pleno (fases 17-19), entre fines del IV y comienzos del III milenio a.C.

El tipo $4 \mathrm{~b}$ de punzones facetados se ha documentado en contextos del Cobre Tardío (fase 20), fechados a mediados del III milenio a.C., en niveles de suelo al extremo sudeste de una de las cabañas que caracterizan el espacio excavado en esta fase, en asociación con una importante concentración de cuernecillos de arcilla, lo que sugiere para ambos elementos, cuernecillos y punzones, una función relacionada con la misma actividad, la textil.

Los punzones del tipo 5 aparecen en contextos cronológicamente similares a aquellos en los que se documentan la mayoría de los punzones del tipo 4a y, muy a menudo, en asociación con aquellos en suelos cubiertos por derrumbes de cabañas de principios del Calcolítico (fases 16b-18) en la transición entre el IV y el III milenios a.C., también cerca de pesas de telar. El ejemplar MF63854 se localizó cerca de un hogar, como también se constata en el caso del punzón MF68050, el único atribuido a niveles del Neolítico Tardío (fase estratigráfica 13), de fines del V milenio a.C.

El único ejemplar de aguja procedente de estas campañas de finales del siglo XX, de principios del III milenio a.C. (fase 17), se localiza también dentro de una cabaña pero en el extremo opuesto del área excavada (al sudeste), en una zona en la que la adecuación de la excavación a los límites del hoyo de los furtivos redujo sustancialmente la superficie objeto de investigación (a unos $20 \mathrm{~cm}$ de anchura apenas) (Ramos et al. 1997), lo que impide relacionar el hallazgo con otros elementos.
La única punta de proyectil fue localizada en un nivel de ocupación cubierto por el derrumbe de la techumbre en el interior de una cabaña de principios del III milenio a.C. (fase estratigráfica 17).

Apuntados indeterminados han sido localizados en todas las fases de Los Castillejos y casi en todos los tipos de contextos identificados, o sea junto a los hogares-hornos del área de producción especializada definida en los niveles adscritos al Neolítico Antiguo y Medio, en el interior de las chozas del Neolítico Tardío y en los suelos de ocupación calcolíticos asociados a los tipos de punzones ya comentados (tipos 4 y 5), especialmente en el caso de los fragmentos agrupados en el número MF61530. Sin embargo, también aparecen numerosos elementos dentro de las fosas, tradicionalmente denominadas silos, en contextos fechados desde el Neolítico Tardío al Cobre Antiguo (desde fines del V milenio a principios del III) (MF68367, MF67819, MF67842, MF67536, MF64260, MF66375), lo que podría sugerir su abandono y desecho como elementos ya no funcionales una vez rotos. Lo mismo se podría pensar de determinados objetos localizados al exterior de las zonas de producción del Neolítico Antiguo y Medio (MF611439, MF64943, MF610029, MF69681, MF69707) o en los límites de las chozas del Neolítico Tardío (MF69707, MF68991 MF68200, MF64965i).

El artefacto definido como mango, localizado en las campañas de 1991-94, se halló en el interior de un hogar-horno de la zona de producción especializada documentada en los contextos de fines del Neolítico Medio (fase estratigráfica 11a, inicios del V milenio a.C.).

El elemento definido como gradina se localizó en los límites del área de producción especializada con hogares-hornos de fines del Neolítico Medio (fase 11a), en una zona en la que aparecen muchos útiles de hueso, fragmentados y desechados, lo que no excluye que este elemento particular se usara en tal área, pese a estar también fragmentado.

El peine fue localizado dentro de una fosa del Neolítico Final (fase 15, segunda mitad del IV milenio a.C.) por lo que también es posible que se desechara junto con el resto de los elementos que constituyen su relleno.

Los colgantes rectangulares aparecen en los contextos especializados que concentran en el área excavada de Los Castillejos estructuras de combustión (hogareshornos) desde fines del VI milenio a.C. pero también en contextos de habitación, que se han considerado (Cámara et al. 2016) simples chozas adosadas al farallón septentrional en el Neolítico Tardío (desde fines del V milenio a.C.), si bien en este caso, un colgante fue localizado en el interior de una fosa y puede pensarse que 


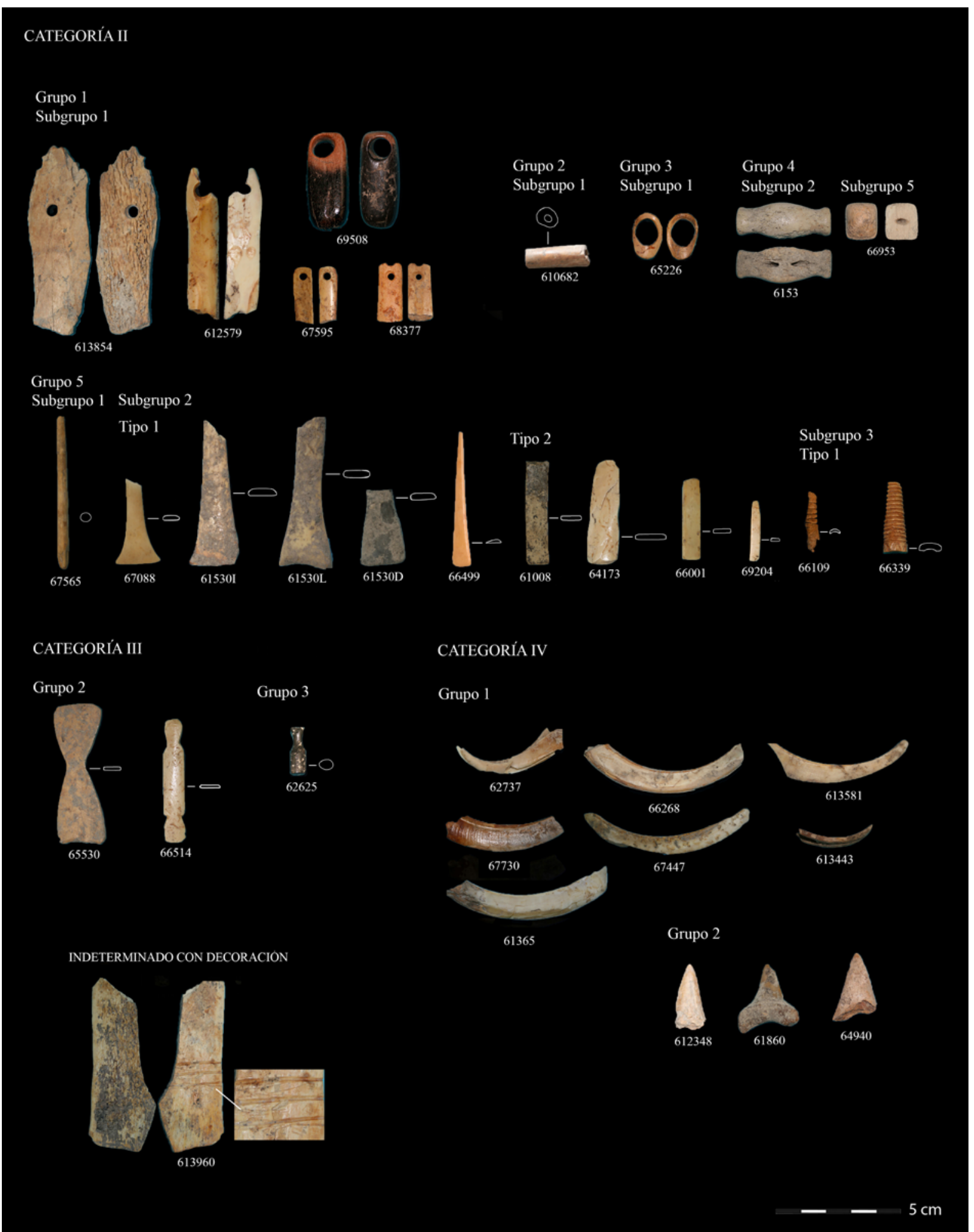

Figura 3. Artefactos de las categorías II, III, IV e Indeterminados. 
había sido desechado intencionalmente y no simplemente perdido o abandonado como la mayor parte del material aquí analizado (MF68377).

La única cuenta cilíndrica localizada en las excavaciones de 1991-94 se halló en los contextos dominados por la abundancia de hogares-hornos del Neolítico Medio (inicios del V milenio a.C.).

También el único anillo analizado, perteneciente a las excavaciones de 1991-94, se halló en el área de concentración de estructuras de combustión del Neolítico Medio (fase estratigráfica 8, inicios del V milenio a.C.).

Mientras el botón con apéndices laterales apareció fuera de contexto en 1991, al retirar la tierra de las afecciones de las excavaciones clandestinas, el botón piramidal procede de contextos de interior de cabaña incendiada del Cobre Reciente no mejor definidos al proceder de la limpieza del perfil.

El alfiler de extremidad apuntada (grupo 1, subgrupo 1) procede de un área de vivienda pero en las cercanías de una fosa del Cobre Antiguo por lo que, aun con su proximidad a otros elementos apuntados y pesas de telar, no se puede descartar que hubiera sido ya desechado antes de la destrucción del contexto de cabaña en que se localiza.

Por el contrario, los alfileres de cabeza diferenciada fija se han localizado muy próximos a distintos tipos de elementos apuntados y pesas de telar en las cabañas del Cobre Antiguo al Tardío (entre fines del IV y mediados del III milenios a.C.), por lo que, aun siendo considerados como adornos, no se podría descartar su uso en ciertas fases de la actividad textil. Del tipo 1, solo el objeto más antiguo, MF66499 (fase 16b), apareció en los límites de una de las cabañas y podría pensarse que fue desechado antes de la destrucción de ésta.

Entre los alfileres de cabeza diferenciada fija del tipo 2, existen diversos ejemplares en contextos de deposición posiblemente secundaria (fosas), realmente los más antiguos, MF69204 y MF64173 de inicios del Cobre Antiguo (fases 13 y 16b), si bien el resto de los elementos calcolíticos de este tipo 2 (MF66001, MF61008, fases 17 y 22) proceden de los niveles de ocupación de cabañas circulares.

Los alfileres con cabeza móvil segmentada o acanalada recuperados en las intervenciones arqueológicas de 1991-94 proceden de niveles de ocupación de cabañas del Cobre Antiguo (fases 16b-17, entre fines del IV y principios del III milenios a.C.) por lo que, como se ha dicho para otros tipos de alfileres, aun considerándose adornos, no se puede descartar un uso en las actividades textiles.
Los dos ídolos planos recuperados en las campañas de excavación de 1991-94, aun perteneciendo a fases estratigráficas bastante distantes, 16b del Cobre Antiguo y $23 \mathrm{~b}$ del Cobre Final, aparecieron en la misma zona, muy cerca del farallón septentrional, en el interior de cabañas calcolíticas circulares.

El ídolo en bulto redondo apareció dentro de una cabaña del Cobre Pleno (segundo cuarto del III milenio a.C.).

Los colmillos de suidos aparecen en todos los periodos y tanto en contextos de habitación (cabañas calcolíticas o chozas del Neolítico Tardío), como de producción especializada (en la zona de hogares-hornos presente en el área excavada entre el Neolítico Antiguo y Medio) y solo en algunos casos se podría pensar en su presencia en ciertas áreas como resultado de un desecho intencionado, especialmente en los contextos más antiguos, al aparecer en una zona de abandono-regularización (MF613443) o dentro de un hogar (MF613581). La misma hipótesis se puede mantener para el objeto del Cobre Antiguo MF66268.

Los dientes de tiburón recuperados en las campañas de excavación de 1991-94 aparecen en las zonas de producción (MF612348) o vivienda.

Al igual que indicamos para los apuntados indeterminados, muchos de los objetos que por su estado de conservación o fracturación no han podido ser adscritos a ningún tipo proceden de contextos a los que debieron llegar por haber sido desechados previamente, sea áreas al exterior de las zonas de actividad (MF610636B, MF611082, MF611038, MF610666, MF610636A, MF69710-1, MF69710A, MF69710B, MF69713, MF69676ABC), sea interiores de fosas (MF66669) u hogares-hornos (MF612844, MF610573, MF610554), e incluso formando parte de las unidades constructivas constitutivas de hogares/hornos o pavimentos (MF611272, MF610459, MF69923). Para el resto de los elementos fragmentados se podría pensar que su deposición, a menudo no intencional, en los suelos de ocupación, facilitó su deterioro por el continuo uso del espacio o por el propio derrumbe tras el abandono.

\subsection{Aspectos técnicos}

El estudio técnico de los artefactos hallados en las intervenciones arqueológicas de 1991-1994 coincide, por lo general, con los resultados obtenidos sobre los materiales de las anteriores excavaciones (Altamirano 2014a: 24-35). 
El único punzón sobre hueso entero, (MF69714), metapodio de ovicáprido, no presenta huellas técnicas, probablemente porque está roto en la punta.

En los punzones sobre hueso hendido (de ovicáprido) que conservan media epífisis (fig. $4 \mathrm{a}, \mathrm{b}$ ) se han podido identificar los trazos de una intensa abrasión en los bordes que afecta también la epífisis. En algunos casos se aprecia una muesca en los bordes del cuerpo, que testimoniaría que las dos mitades del hueso se separaron por percusión indirecta, después de haber preparado previamente la faceta.

El artefacto que hemos definido como esquirla de hueso largo, MF611785, seguramente se obtuvo, como se ha propuesto para las piezas de las excavaciones previas (Altamirano 2014a: 28), mediante la fracturación del bloque original en varios fragmentos irregulares de diverso tamaño, con la confección de la punta por abrasión como única modificación del soporte (fig. 4c).

Los punzones facetados totalmente, del tipo 4a, presentan estrías longitudinales y oblicuas de la regularización de la superficie por abrasión, aunque en el tipo $4 \mathrm{~b}$ se constata, todavía, el canal medular de la diáfisis. Los del tipo 5 examinados presentan facetada la totalidad de sus superficies.

En la aguja MF63471 se han encontrado huellas de abrasión y la perforación bipolar posiblemente realizada con un taladro.

La punta de proyectil MF61656, por su mal estado de conservación y por la alteración térmica de su superficie, solo permite apreciar estrías oblicuas de abrasión en la punta.

En el mango MF610242 son visibles estrías del proceso de regularización por abrasión en todo el cuerpo y en las dos extremidades (fig. 5a).

En lo que respecta a los útiles dentados, en la gradina MF69721 no se han podido definir, por su mal estado de conservación, las técnicas de fabricación, mientras el pequeño peine MF68495 se obtuvo recortando el hueso y configurando el cuerpo y el apéndice trapezoidal por abrasión como se desprende del carácter contiguo de las estrías. Los dientes se realizaron en el extremo opuesto con la técnica de ranurado bifacial, incisiones largas y profundas que continúan hasta el interior del cuerpo superando el espacio interdental (Altamirano 2014b: 31; Maicas 2007: 156; Pau y Cámara 2018: 230).

El colgante subrectangular MF613854 se manufacturó recortando simplemente el hueso, mientras el agujero de suspensión se realizó con un taladro como demuestran las estrías concéntricas en su interior. El colgante subrectangular MF612579 (fig. 5b) se elaboró cortando longitudinalmente un colmillo de Sus scrofa para obtener una pieza más pequeña. Después se regularizó la superficie interna con abrasión y pulido, que dejaron estrías finas, quedando la parte externa al natural. En el extremo superior se realizó una perforación unipolar con un taladro, como indican las estrías concéntricas en su interior. La alteración térmica del colgante subrectangular MF69508 ha hecho que solo se hayan identificado, en el extremo superior, estrías finas de la fase de regularización (Pau y Cámara 2018: 230). Los dos colgantes MF67595, MF68377, presentan un grado de facetado total, conseguido por abrasión, aunque el segundo adorno conserva todavía la oquedad del hueso, siendo posteriormente pulidos. Las perforaciones fueron realizadas desde las dos caras, testimoniando la presencia de estrías concéntricas en los bordes internos del orificio el uso de un taladro (Pau y Cámara 2018: 230).

La cuenta cilíndrica MF610682 fue manufacturada partiendo de un hueso largo, cuya diáfisis fue seccionada transversalmente en ambos extremos por aserrado o tallado, como se ha comprobado en otros contextos (Pascual 1998: 119), y finalmente la superficie fue regularizada por abrasión y pulido como se aprecia por las finas estrías en los bordes de la cuenta (Pau y Cámara 2018: 230).

En el anillo-colgante MF65226 se observa la última fase de manufactura, el pulido de la superficie.

El estudio traceológico de los botones ha sido obstaculizado por su degradación superficial. Se han encontrado solo indicios de abrasión en la cara ventral del botón piramidal MF66953 (Pau y Molina 2015: 107).

Todos los alfileres examinados presentan facetada la totalidad de sus superficies, con algunas excepciones (MF61530I, MF61530L, MF61530D y MF61008), y en la mayoría de las piezas se han identificado la abrasión y el pulido. Las cabezas diferenciadas se realizaron probablemente con el tallado y el raspado transversal como sugieren otros investigadores (Pascual 1998: 110), terminando el trabajo con abrasión y pulido muy fino como atestiguan las huellas identificadas en algunos de los objetos estudiados (MF67088, MF66499, MF64173, MF66001, MF69204, MF66109 y MF66339). Además, las dos cabezas móviles estudiadas conservan en una cara, todavía visible, la concavidad del canal medular del hueso (Pau y Cámara 2018: 230).

En los ídolos se han encontrado trazas solo en el MF66514 del grupo $1 \mathrm{y}$ en el pequeño ejemplar del grupo 2, estrías transversales a su eje máximo producidas por la abrasión y brillo de pulido en la totalidad 


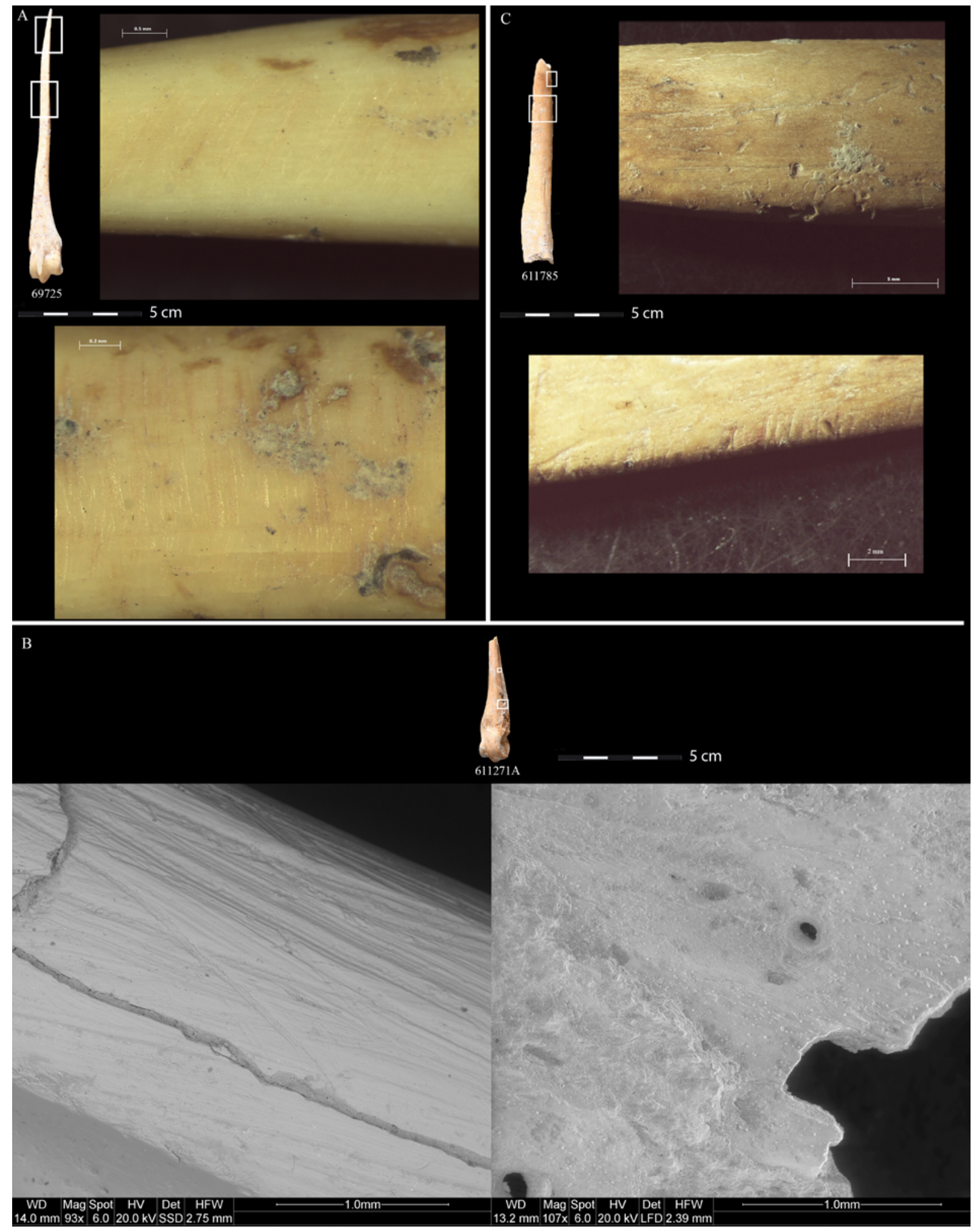

Figura 4. A) Huellas de abrasión del punzón MF69725; B) Huellas técnicas en el punzón MF611271A; C) Estrías de abrasión en el artefacto MF611785. 


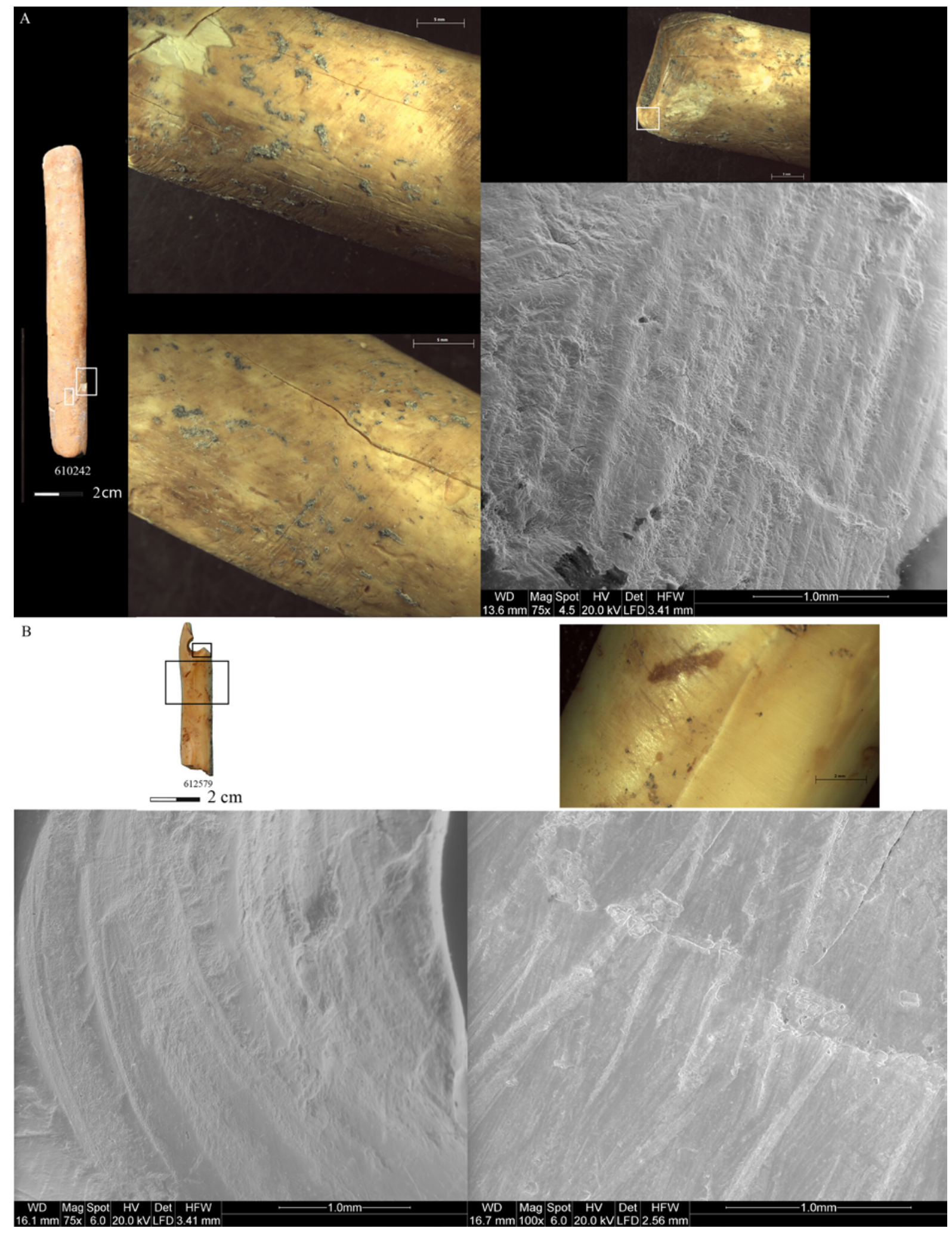

Figura 5. A) Estrías del proceso de regularización en el mango MF610242; B) Trazas tecnológicas en el colgante MF612579 (Pau y Cámara 2018: 231 Fig. 12A), estrías concéntricas en el interior de la perforación y huellas de abrasión en la cara superior. 
de su superficie. El análisis de las cuatro escotaduras del ídolo plano MF66514 nos lleva a señalar que fueron realizadas por cortes oblicuos probablemente con un instrumento de sílex, coincidiendo con lo observado en otros casos (Pascual 1998: 186).

Algunos de los fragmentos de colmillos de Sus Scrofa fueron obtenidos recortando longitudinalmente los colmillos, pero solo en dos ejemplares, MF67447 y MF613581, se han encontrado huellas de regularización, finas estrías de abrasión.

En los dientes fósiles de tiburón no se han encontrado evidencias de trasformación antrópica de ningún tipo.

\subsection{Aspectos funcionales}

Hemos definido como punzones los apuntados que se pueden relacionar con la realización de perforación simple manual, aunque solo en pocos ejemplares ha sido posible identificar trazas de uso (MF611153, MF610887, MF65850, MF61516).

Estos instrumentos vienen actualmente relacionados con varias actividades como la perforación de piel y cuero, la elaboración de artefactos en esparto, cáñamo o corteza, e incluso la apertura de frutos, la limpieza de pescado o la realización de tatuajes (Jover y López 2013: 162). Sin embargo, en nuestro caso específico, podemos sugerir que una parte relevante de estos instrumentos se relaciona con actividades textiles, como testimoniaría su asociación espacial a otros artefactos en todas las fases calcolíticas del yacimiento. En el Cobre Antiguo (fases 16b y 17), punzones de los tipos 4 a y 5 se asocian a pesas de telar y placas de forma trapezoidal, apareciendo también cerca de ellos determinados tipos de alfileres, especialmente los de cabeza diferenciada fija. En las fases 19 y 20, en asociación con punzones facetados de los subtipos 4a y $4 \mathrm{~b}$, encontramos numerosos cuernecillos, en torno a 70 en el segundo caso.

Aunque no se han encontrado trazas de uso en la aguja MF63471, nos parece probable la relación de este tipo de instrumento con la costura.

En la punta de proyectil MF61656 y en la gradina MF69721 no ha sido posible identificar ninguna huella por su mal estado de conservación y alteración térmica.

En el instrumento MF610242 no hemos encontrado ningún resto del artefacto enmangado, aunque, considerando el tamaño de los orificios y estudios de otros contextos (Pascual 1998: 92), podemos pensar en puntas óseas, metálicas o de piedra tallada, para configurar escoplos o cinceles. Además, el artefacto presenta profundas muescas en las extremidades que pueden haber sido provocadas por las vibraciones de la percusión y su presión sobre el soporte (fig. 6a).

A los elementos dentados (subgrupo 2) tradicionalmente se atribuyen diferentes funciones: instrumentos utilizados para decorar la cerámica, útiles para las actividades textiles o la limpieza de pieles, objetos de adorno personal como colgantes o peinetas para el cabello o partes del tocado, amuletos o elementos simbólicos (Castro 1988; Pascual 1998: 86) o peines usados para arreglar y limpiar el cabello. Aunque la serie de surcos en la base de los dientes identificados en el objeto estudiado ha sido relacionada, en los peines de las excavaciones antiguas, con el uso en el acondicionamiento del cabello por la acción combinada de grasa, suciedad y polvo (Altamirano 2014a: 30-32; 2014b; 2014c: 158), dudamos de esta hipótesis considerando el tamaño reducido (menos de $5 \mathrm{~mm}$ ) de los dientes del artefacto estudiado, pudiéndose pensar más en un uso ornamental (Pau y Cámara 2018: 235).

Se han detectado zonas de pulido, posiblemente producidas por el roce de los objetos de adorno con las vestimentas o la piel de quien los llevaba, en la cara inferior y en los márgenes del colgante subrectangular MF69508, en el que también hay áreas de brillo en la superficie de la perforación creadas por el roce de una cuerda o un hilo de suspensión. Se ha determinado además que la rotura de los colgantes subrectangulares MF612579 y MF67595 es reciente, mientras que la del orificio del artefacto MF68377 se produjo en antiguo. Probablemente después de esta rotura se consideró oportuno reparar el objeto realizando un segundo agujero y regularizando los bordes de la fractura, si bien no podemos descartar que este adorno en origen hubiera tenido dos agujeros, para ser usado como separador de cuentas, y sólo después de la rotura de una de las dos perforaciones el objeto fuese restaurado y usado como colgante (Pau y Cámara 2018: 232).

La cuenta cilíndrica MF610682 presenta una muesca en el borde, probablemente determinada por el método de sujeción (fig. 6b).

El pequeño elemento anular MF65226 puede ser interpretado como un colgante, un elemento utilizado en la decoración del cabello o vestimenta o un pequeño anillo para individuos infantiles o de constitución grácil, aunque no se han encontrado huellas de uso (Pau y Cámara 2018: 234).

El mal estado de conservación de los adornos del grupo 4 no ha permitido obtener datos sobre su uso, aunque los hemos denominado como botones por las 


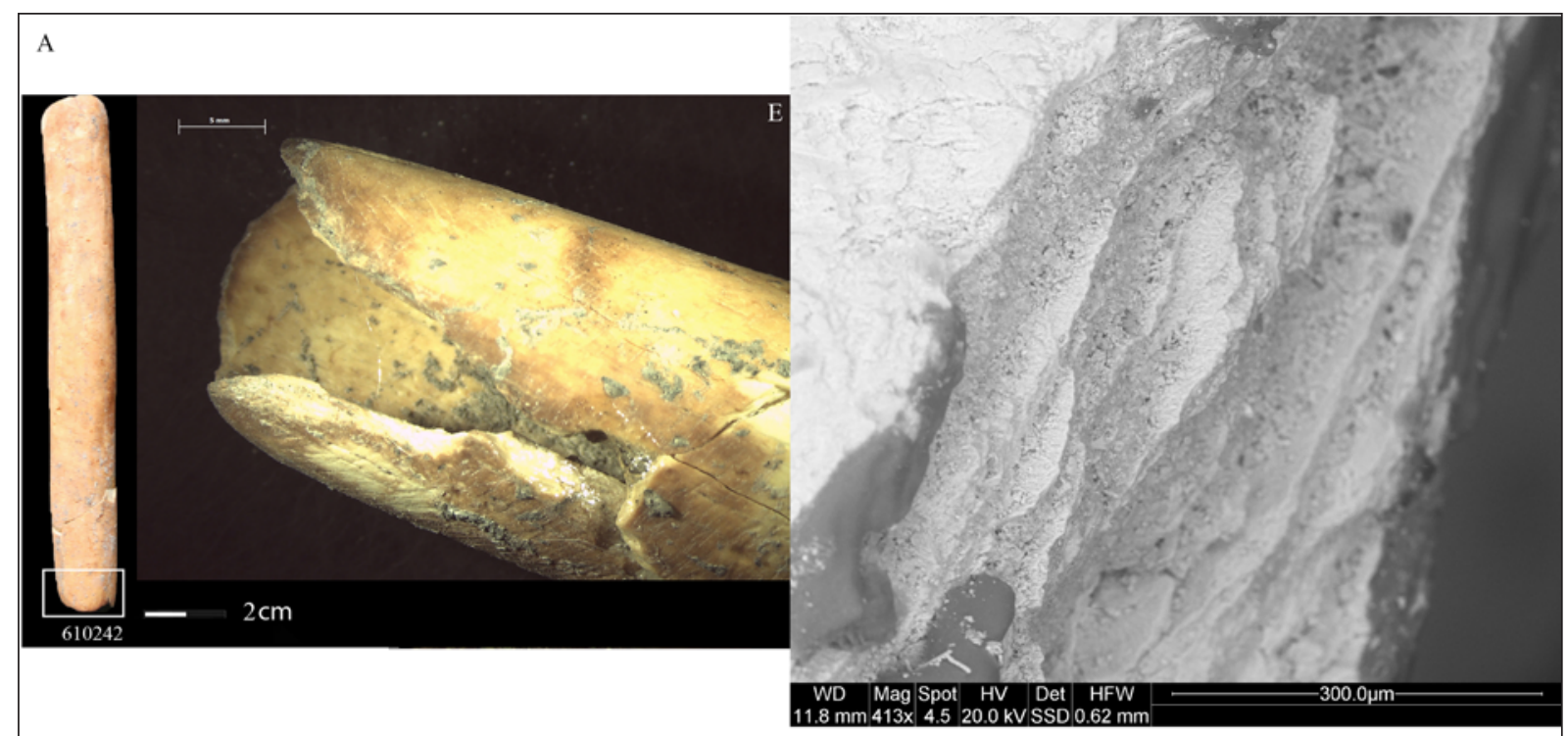

B

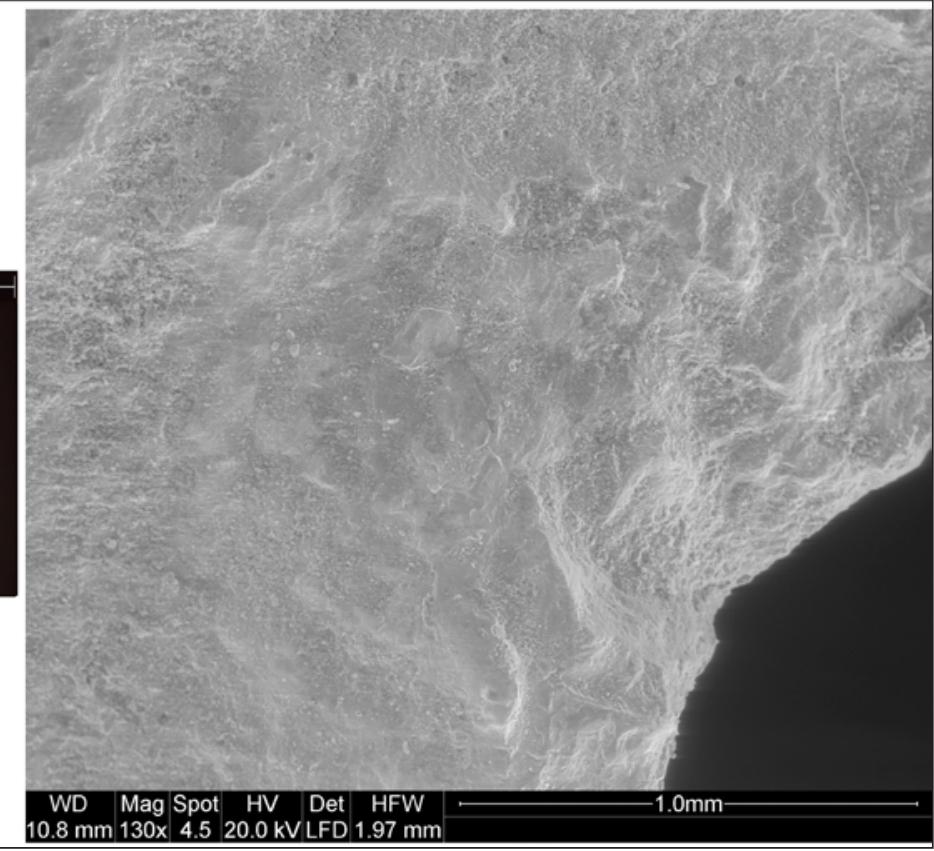

Figura 6. A) Muescas de uso en la extremidad del mango MF610242; B) Muescas en la cuenta MF610682.

analogías formales con los objetos actuales que denominamos así (Pau 2016: 862), si bien hay diferentes interpretaciones sobre su funcionalidad: botones, cuentas, colgantes, "lúnulas", separadores de collar, adornos para vestidos, elementos que formaban los pectorales u objetos situados en la cuerda de los arcos para mejorar el disparo (Uscatescu 1992: 20-21; López 2011: 464). En cualquier caso, se han encontrado, en otros contextos, varios indicios que siguieren el uso de estos objetos. Se han relacionado con las vestimentas, para abrocharlas o decorarlas, debido a su posición respecto a los esqueletos, y también por las manchas de colorante rojo (cinabrio o almagra), que podría haber sido el colorante utilizado para teñir las prendas de vestir (López 2011: 464-465). En otros casos, como en el Cerro de la Virgen (Orce), las trazas de uso han mostrado el paso del hilo usado para coserlos a la vestimenta o para colgarlos al cuello (Pau et al. 2018: 277-280, 286).

No se han identificado trazas de uso en los alfileres, aunque podrían haber sido utilizados como adornos 
para el cabello o para cerrar las vestimentas (Pau 2016: 864), lo que podría explicar la asociación de varios tipos a los punzones.

En los colmillos de suidos no se han encontrado ni trazas de uso ni ningún tipo de elemento que pudiera haber sido utilizado para su sujeción. Podría tratarse de objetos en fase de elaboración o en algunos casos (MF67730, MF613581) podría haberse perdido la parte donde estaba el elemento de sujeción (orificio, acanaladuras etc.). Podrían haber tenido varios usos: colgantes, gargantillas formadas por dos defensas de jabalí unidas en las extremidades, elementos cosidos en las vestimentas o grandes pendientes utilizados para decorar narices u otras partes del cuerpo (Pau 2016: 862).

Aunque el análisis macro y microscópico no ha dado ningún resultado, los dientes de tiburón podrían haber tenido, como se propone para los dientes de otros animales (canidos, cérvidos, etc.), un significado protector o apotropaico (Pau 2016: 861,882).

\section{DISCUSIÓN}

De los soportes utilizados para la manufactura de los objetos, el hueso es el predominante para la fabricación de los artefactos $(88,47 \%)$ seguido por los dientes y colmillos de animales, cérvidos, suidos y tiburones, estos últimos fósiles $(5,08 \%)$. Más escasos son los artefactos manufacturados en marfil $(3,39 \%)$ o asta de ciervo (3,05\%) (tab. 3 ).

En cuanto a las especies, los ovicápridos son los animales mejor representados, seguidos por suidos, bóvidos y cérvidos (tab. 3). Estos datos podrían estar distorsionados ya que de muchos artefactos no se ha podido identificar la especie utilizada, por su alto grado de transformación o deterioro. Solo en el caso del marfil podemos hablar de soporte alóctono.

De los ovicápridos se utilizaban prevalentemente los huesos largos (tibias y metápodos), de los suidos los colmillos y las fíbulas, de los bóvidos las costillas y de los cérvidos sobre todo el asta (tab. 3). De hecho, se utilizarían los huesos largos de animales grandes para manufacturar útiles y alfileres y los de animales más pequeños para confeccionar colgantes o cuentas. Concretamente, las costillas de bóvidos fueron hendidas para los colgantes subrectangulares, los elementos dentados y los punzones laminares (tipo 4b), los colmillos de suido se usaron probablemente para colgantes en forma de arco y las fíbulas para punzones y agujas, mientras las astas sirvieron para mangos, botones y apuntados. Los artefactos manufacturados en marfil son adornos, un colgante rectangular y botones.

Los materiales calcolíticos proceden de áreas de habitación, los del Neolítico Antiguo y Medio de áreas de concentración de estructuras de combustión y los del Neolítico Tardío y Final de fosas o espacios entre ellas. Además cabe señalar, dentro de estos aspectos generales, que muchos de los elementos que, por su estado, no se han podido clasificar proceden de contextos que pueden sugerir su desecho intencional, ya sea en el exterior de las áreas referidas, dentro de hogares o silos o incluso como elementos incluidos en las estructuras de barro que conforman las unidades constructivas de pavimentos, bancos u hogares/hornos. Por otro lado, algunos elementos, especialmente los punzones de los tipos 4 y 5 y los alfileres del subgrupo 2, muestran localizaciones en las cabañas calcolíticas asociadas a elementos como pesas de telar y cuernecillos de arcilla que apoyan su relación con las diferentes fases de la confección de las vestimentas.

Podemos observar que en la categoría I (tab. 4), hay útiles presentes desde las fases más antiguas del yacimiento (Neolítico Antiguo) hasta el Bronce Antiguo como los punzones sobre hueso hendido que conservan media epífisis, aunque en las campañas de los años 90 estos objetos solo se han localizado en contextos del Neolítico Medio. Mayor concordancia en los datos obtenidos de los materiales de las diferentes campañas la encontramos en otros útiles de larga perduración, los punzones facetados con el canal medular todavía visible que llegan hasta el Cobre Tardío. Otros útiles también tienen un amplio desarrollo temporal, como los punzones sobre hueso entero que aparecen desde el Neolítico Medio, o los realizados sobre esquirlas de hueso largo desde el Neolítico Final. Los punzones facetados sin canal medular visible y los laminares sobre costilla aparecen en momentos anteriores del Neolítico Tardío, pero se constatan solo hasta el Cobre Pleno. Para el resto de los útiles su escaso número impide extraer conclusiones sobre su desarrollo temporal, aunque puede resultar significativa la aparición de algunos solo en momentos de transición al Calcolítico, como sería el caso de los peines.

Está claro que algunos adornos (categoría II) (tab. 4) son característicos de las fases neolíticas del yacimiento, como los colgantes rectangulares, con una evolución en su morfología, ya que desde formas muy irregulares se pasará a subrectangulares con los ángulos redondeados y a rectas en el Neolítico Reciente (Pau y Cámara 2018: 236). Otros adornos no se atestiguan 
Tabla 3. Materias primas utilizadas, especies de animales vertebrados empleadas, partes anatómicas de ovicápridos, suidos, bóvidos y cérvidos utilizadas para la manufactura de los artefactos.

\begin{tabular}{|l|c|}
\hline hueso & $88,47 \%$ \\
\hline marfil & $3,39 \%$ \\
\hline asta & $3,05 \%$ \\
\hline Colmillos y dientes & $5,08 \%$ \\
\hline
\end{tabular}

\begin{tabular}{|l|l|}
\hline \multicolumn{1}{|c|}{ Especie } & \multicolumn{1}{|c|}{$\%$} \\
\hline $\begin{array}{l}\text { Ovicápridos } \\
\text { Capra hircus o Ovis aris }\end{array}$ & 12,88 \\
\hline $\begin{array}{l}\text { Suidos } \\
\text { Sus scrofa o Sus domesticus }\end{array}$ & 7,45 \\
\hline $\begin{array}{l}\text { Bóvidos } \\
\text { Bos taurus o Bos domesticus }\end{array}$ & 4,06 \\
\hline $\begin{array}{l}\text { Cervidos } \\
\text { Cervus Elaphus }\end{array}$ & 4,06 \\
\hline Marfil & 3,34 \\
\hline $\begin{array}{l}\text { Tiburón } \\
\text { Hisurus hastalis }\end{array}$ & 1,69 \\
\hline Carnívoro & 1,35 \\
\hline Lince (Lynxsp.) & 0,34 \\
\hline Équido (Equss sp) & 0,34 \\
\hline Animales de pequeña o media talla & 11,18 \\
\hline Animales de media o grande talla & 33,56 \\
\hline No identificado & 20 \\
\hline
\end{tabular}

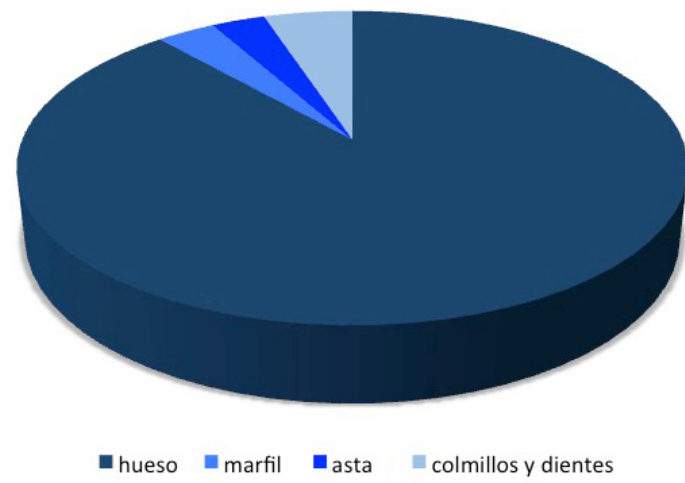

\begin{tabular}{|l|l|l|}
\hline \multicolumn{1}{|c|}{ Especie } & Parte anatómica & \multicolumn{1}{c|}{$\%$} \\
\hline \multirow{4}{*}{$\begin{array}{l}\text { Ovicápridos } \\
\text { Capra hircus o Ovis aris }\end{array}$} & Tibia & $44,74 \%$ \\
\cline { 2 - 3 } & Metápodo & $44,74 \%$ \\
\cline { 2 - 3 } & Costilla & $7,89 \%$ \\
\cline { 2 - 3 } & Tibia /metápodo & $2,63 \%$ \\
\hline \multirow{2}{*}{$\begin{array}{l}\text { Suidos } \\
\text { Sus scrofa o }\end{array}$} & Colmillo & $40,91 \%$ \\
\cline { 2 - 3 } $\begin{array}{l}\text { Súvidos domesticus } \\
\text { Bos taurus o } \\
\text { Bos domesticus }\end{array}$ & Fíbula & $50,09 \%$ \\
\hline \multirow{2}{*}{$\begin{array}{l}\text { Cervidos } \\
\text { Cervus Elaphus }\end{array}$} & Costilla & 100 \\
\hline
\end{tabular}

hasta la Edad del Cobre, como los alfileres con cabeza diferenciada fija. Los botones aparecen por primera vez en el Cobre Tardío (a casquete esférico, con apéndices laterales, cónicos, probablemente cilíndricos y uno piramidal) y están presentes en el yacimiento hasta el Bronce Antiguo, cuando aparece la forma prismática. Se ha constatado también en el Cerro de la Virgen, en la misma provincia granadina, que tanto esta forma prismática como la piramidal son las más recientes (Pau et al. 2018).
Los ídolos (categoría III) (tab. 4) aparecen por primera vez en el Cobre Antiguo cuando encontramos los ídolos falanges, constatados también en el Cobre Final, y los ídolos planos, presentes también en el Cobre Tardío. En niveles del Cobre Pleno aparecen por primera vez ídolos en bulto redondo. Lamentablemente el escaso número impide extraer conclusiones cronológicas y lo mismo se puede decir de su aparente concentración en el extremo noreste del área excavada. 
Tabla 4. Evolución cronológica de los útiles (categoría I), de los adornos (categoría II) y de otros artefactos (categoría III y IV) en materia dura de animales vertebrados del yacimiento de Los Castillejos en La Peñas de los Gitanos de Montefrío.

\begin{tabular}{|c|c|c|}
\hline \multicolumn{3}{|c|}{ Categoría I } \\
\hline \multirow{2}{*}{ Neolítico Antiguo } & MF612369, MF611590, MF611153 & grupo 1 , subgrupo1, tipo 2 \\
\hline & MF613815 & grupo 1 , subgrupo1, tipo $4 \mathrm{a}$ \\
\hline \multirow{5}{*}{ Neolítico Medio } & MF69714 & grupo 1 , subgrupo1, tipo 1 \\
\hline & MF610242 & grupo 4 , subgrupo 1 \\
\hline & MF69721 & grupo 5 , subgrupo 1 \\
\hline & $\begin{array}{l}\text { MF611334, MF611404, MF611271A, MF610887, } \\
\text { MF610478, MF69725, MF69720, MF610424 }\end{array}$ & grupo 1 , subgrupo 1 , tipo 2 \\
\hline & MF611890 & grupo 1 , subgrupo1, tipo $4 \mathrm{a}$ \\
\hline \multirow{3}{*}{$\begin{array}{l}\text { Neolítico Final/Cobre An- } \\
\text { tiguo }\end{array}$} & MF6088A & grupo 1 , subgrupo 1 , tipo 1 \\
\hline & MF6088B & grupo 1 , subgrupo 1 , tipo 2 \\
\hline & MF6008c & grupo 2 \\
\hline \multirow{2}{*}{ Neolítico Final } & MF241, MF242 & grupo 1 , subgrupo 1 , tipo 3 \\
\hline & MF68495 & grupo 5 , subgrupo 2 \\
\hline \multirow{7}{*}{ Cobre Antiguo } & MF3753, MF2216 & grupo 1 , subgrupo 1 , tipo 1 \\
\hline & MF2269, MF2274, MF2280, MF2281 & grupo 1 , subgrupo1, tipo 3 \\
\hline & $\begin{array}{l}\text { MF61829, MF66263, MF66264, MF2189, MF2194, } \\
\text { MF2274 }\end{array}$ & grupo 1 , subgrupo1, tipo $4 \mathrm{a}$ \\
\hline & MF3763 & grupo 1 , subgrupo1, tipo $4 \mathrm{~b}$ \\
\hline & MF2252 & grupo 1 , subgrupo1, tipo 5 \\
\hline & MF63471 & grupo 1 , subgrupo 2 \\
\hline & MF61656 & grupo 1 , subgrupo 3 \\
\hline \multirow{2}{*}{ Cobre Antiguo/ Cobre Pleno } & MF734 & grupo 1 , subgrupo1, tipo 1 \\
\hline & MF198 & grupo 1 , subgrupo1, tipo $4 \mathrm{a}$ \\
\hline \multirow{5}{*}{ Cobre Pleno } & MF180, MF2127 & grupo 1 , subgrupo1, tipo 1 \\
\hline & MF656, MF2130, MF2189, MF2234 & grupo 1 , subgrupo1, tipo 3 \\
\hline & MF65850, MF62610, MF656 & grupo 1 , subgrupo1, tipo $4 \mathrm{a}$ \\
\hline & MF175 & grupo 1 , subgrupo1, tipo $4 \mathrm{~b}$ \\
\hline & MF148, MF163, MF164 & grupo 1 , subgrupo1, tipo 5 \\
\hline \multirow{3}{*}{ Cobre Tardío } & MF135, MF162, MF658, MF3610, MF692 & grupo 1 , subgrupo1, tipo 1 \\
\hline & MF692, MF3632 & grupo 1 , subgrupo1, tipo 2 \\
\hline & MF2075 & grupo 1 , subgrupo1, tipo $4 \mathrm{a}$ \\
\hline
\end{tabular}




\begin{tabular}{|c|c|c|}
\hline \multicolumn{3}{|c|}{ Categoría I } \\
\hline \multirow{4}{*}{ Cobre Tardío/Cobre final } & MF611785 & grupo 1 , subgrupo1, tipo 3 \\
\hline & MF61516, MF61530F & grupo 1 , subgrupo1, tipo $4 \mathrm{~b}$ \\
\hline & MF125, MF3576, MF3610, MF 3611, MF3683 & grupo 1 , subgrupo1, tipo 5 \\
\hline & MF3627 & grupo 3 \\
\hline Cobre Final & MF3286 & grupo 2 \\
\hline \multirow{4}{*}{ Bronce Antiguo } & MF3272, MF3165 & grupo 1, subgrupo1, tipo 1 \\
\hline & MF8005 & grupo 1 , subgrupo1, tipo 2 \\
\hline & MF3175, MF3225 & grupo 1 , subgrupo 2 \\
\hline & MF3090 & grupo 2 \\
\hline \multicolumn{3}{|c|}{ Categoría II } \\
\hline Neolítico Antiguo & MF613854, MF612579 & grupo 1 , subgrupo 1 \\
\hline \multirow{3}{*}{ Neolítico Medio } & MF69508 & grupo 1 , subgrupo1 \\
\hline & MF610682 & grupo 2, subgrupo1 \\
\hline & MF65226 & grupo 3 \\
\hline \multirow{3}{*}{ Neolítico Tardío } & MF67595, MF68377 & grupo 1 , subgrupo 1 \\
\hline & MF68050 & grupo 5 , subgrupo 1 , Tipo 1 \\
\hline & MF69204 & grupo 5 , subgrupo 2 , Tipo 2 \\
\hline \multirow{5}{*}{ Cobre Antiguo } & MF63422 y MF638541 MF2193 & grupo 5 , subgrupo 1 , Tipo 1 \\
\hline & MF67565 & grupo 5 , subgrupo 1 , Tipo 2 \\
\hline & MF 66499 & grupo 5 , subgrupo 2 , Tipo 1 \\
\hline & MF64173 y MF66001 & grupo 5 , subgrupo 2 , Tipo 2 \\
\hline & MF66109, MF66339 & grupo 5, subgrupo 3, Tipo 1 \\
\hline \multirow{3}{*}{ Cobre Pleno } & MF. 858 & grupo 2, subgrupo1 \\
\hline & MF67066, MF2147, MF2211 & grupo 5 , subgrupo 1 , Tipo 1 \\
\hline & MF67088 & grupo 5 , subgrupo 2 , Tipo 1 \\
\hline \multirow{9}{*}{ Cobre Tardío } & MF. 2.224 & grupo 1 , subgrupo2 \\
\hline & MF10019 & grupo 4 , subgrupo1, tipo 1 \\
\hline & MF3217 & grupo 4 , subgrupo1, tipo 2 \\
\hline & MF3203, MF 6153 & grupo 4 , subgrupo 2 \\
\hline & MF3218 & grupo 4 , subgrupo3 \\
\hline & MF2260, MF22 & grupo 4 , subgrupo4 \\
\hline & MF66953, MF111 & grupo 4, subgrupo 5 \\
\hline & MF144, MF149 & grupo 5 , subgrupo 2 , Tipo 1 \\
\hline & MF 61008 & grupo 5 , subgrupo 2 , Tipo 2 \\
\hline
\end{tabular}




\begin{tabular}{|c|c|c|}
\hline \multicolumn{3}{|c|}{ Categoría II (continuación) } \\
\hline \multirow{3}{*}{ Cobre Final } & MF7009 & grupo 1 , subgrupo3 \\
\hline & MF 2002 & grupo 4 , subgrupo 5 \\
\hline & MF61530D, MF61530I, MF61530L & grupo 5 , subgrupo 2 , Tipo 1 \\
\hline \multirow{2}{*}{ Bronce Antiguo } & MF 1014 & grupo 4, subgrupo 6 \\
\hline & MF3198 & grupo 5 , subgrupo 2 , Tipo 1 \\
\hline \multicolumn{3}{|c|}{ Categoría III } \\
\hline \multirow{2}{*}{ Cobre Antiguo } & MF66154 & grupo 1 \\
\hline & MF2312 & grupo 2 \\
\hline Cobre Pleno & MF62625 & grupo 3 \\
\hline Cobre Tardío & MF133 & grupo 2 \\
\hline Cobre Final & MF65530 & grupo 1 \\
\hline \multicolumn{3}{|c|}{ Categoría IV } \\
\hline \multirow{2}{*}{ Neolítico Antiguo } & MF612348 & grupo 1 \\
\hline & MF613443, MF613581 & grupo2 \\
\hline \multirow{2}{*}{ Neolítico Tardío } & MF64694 & grupo 1 \\
\hline & MF67730 & grupo 2 \\
\hline Cobre Antiguo & MF67447, MF66268 & grupo 2 \\
\hline \multirow{2}{*}{ Cobre Pleno } & MF186 & grupo 1 \\
\hline & MF62737 & grupo 2 \\
\hline \multirow{2}{*}{ Cobre Tardío } & MF61860 & grupo 1 \\
\hline & MF613650 & Grupo2 \\
\hline Bronce Antiguo & MF3280 & grupo 1 \\
\hline
\end{tabular}

Los dientes y los colmillos de la categoría IV (tab. 4) aparecen prácticamente a lo largo de toda la secuencia.

Entre los materiales estudiados destaca la presencia de objetos decorados: los indeterminados MF612173, MF613359, MF613960 del Neolítico Antiguo, el punzón sobre hueso hendido que conserva media diáfisis MF611271A del Neolítico Medio, las cabezas de alfileres MF66109, MF66339 del Cobre Antiguo y el botón prismático MF1014 del Bronce Antiguo. Todos estos artefactos presentan una decoración incisa, a menudo con líneas paralelas rectas u oblicuas. Aunque en relación con las incisiones de los útiles apuntados, algunos investigadores las interpretan como producto de una acción preparatoria para el afilado con la técnica de la abrasión (López 2011: 334), en nuestro caso específico esta hipótesis solo sería aplicable al caso particular del artefacto MF612173.

En cuanto a los paralelos, los punzones de tipología tubular sobre tibia entera de ovicáprido se documentan en el cuadrante sudeste de la península ibérica en contextos del III milenio como El Malagón (Cúllar) y Los Millares (Santa Fe de Mondújar) y de la Edad del Bronce como, por ejemplo, en la Motilla del Azuer (Daimiel), Cerro de la Encantada (Granátula de Calatrava), Cerro del Cuchillo (Almansa), Lloma de Betxí (Paterna), Laderas del Castillo (Callosa de Segura), El Argar (Antas), Cerro de la Virgen y Castellón Alto (Galera) (Altamirano 2013a: 121-122). Fuera del cuadrante sudeste encontramos paralelos en Cueva del Moro (Tarifa) o Los Tolmos (Caracena) (Altamirano 
2013a: 121-122). Los punzones sobre metápodo entero de ovicáprido en España se documentan con anterioridad al IV milenio a.C. en particular en las zonas oriental y meridional, perdurando en el III con casos como Los Millares o el Cerro de Virgen, siendo más escasos durante el II milenio a.C. en El Oficio (Cuevas del Almanzora) o Motilla de Azuer (Altamirano 2013a: 127-128). Los punzones de fíbula entera son muy conocidos en Europa y presentan una amplia cronología, desde el Paleolítico hasta la Edad de los Metales (Maicas 2007: 126). Los de suido en España se han documentado en varios yacimientos calcolíticos como Almizaraque (Cuevas del Almanzora), Cerro de la Virgen, Los Millares o El Malagón, o de la Edad del Bronce como Peñalosa (Baño de la Encina), Cuesta del Negro (Purullena), Cerro de la Encina (Monachil), El Argar, El Oficio y Fuente Álamo (Cuevas del Almanzora), Gatas (Turre), La Bastida (Totana), Cabezo Redondo (Villena), La Encantada y Motilla de Azuer, entre otros (Altamirano 2013a: 131-133; Maicas 2007: 125-127). Los útiles en fíbulas de carnívoros o de aves se han documentado en varios contextos del II y III milenios a.C. del mismo cuadrante sudeste de la Península como Motilla de Azuer, Cerro del Cuchillo, Cabezo Redondo, El Argar, Cerro de la Virgen, Los Millares o Almizaraque, pero también aparecen el nordeste de España en Moncín (Borja) (Maicas 2007: 126; López 2011: 385, 386; Altamirano 2013a: 134). Los punzones sobre hueso entero de costilla de mesomamífero son un útil bastante raro, encontrándose un ejemplar parecido al de Los Castillejos en El Malagón (Altamirano 2013a: 134). Los punzones sobre metápodo lateral de équido se documentan desde el III milenio a.C. hasta la Edad del Bronce en España con ejemplos como los de Almizaraque, Gatas, Cerro de la Encina y Motilla de Azuer (Maicas 2007; Altamirano 2013a: 135).

Los punzones sobre hueso hendido (metápodos o tibias) de ovicáprido o de otros rumiantes que conservan media epífisis se documentan en Europa desde el Neolítico hasta época romana (Camps-Fabrer et al. 1990) y se localizan en España desde contextos neolíticos como Cueva de Nerja (Nerja), Los Murciélagos (Zuheros), Cova Gran (Santa Liña) o cueva de Chaves (Casbas de Huesca) (Pascual 1998: 51), pero también en yacimientos de la Edad del Bronce del cuadrante sudeste de la península ibérica como Motilla de Azuer, Cerro del Cuchillo o Tabaiá (Aspe) (López 2011: 369). En la provincia de Granada se había propuesto, hasta hora, su presencia desde el Neolítico hasta, en menor número, el Calcolítico precampaniforme (Salvatierra 1982: 233; Pascual 1998: 51), mientras que Los Castillejos atestigua su uso hasta el Bronce Antiguo, si bien, como hemos dicho, si atendemos sólo a los materiales de las campañas de los años 90 del siglo XX habría que plantear que fundamentalmente son objetos neolíticos.

Los punzones del tipo 3 (esquirlas de hueso largo), por su fácil manufactura, son útiles que tienen una amplia distribución espacial y caracterizan todas las etapas prehistóricas, siendo propios de los contextos de hábitat (Pascual 1998: 40; Maicas 2007: 124).

Los punzones facetados, sobre hueso largo con y sin canal medular visible, se conocen en varias zonas europeas ya desde el Paleolítico, y en el este de la península ibérica estos tipos de útiles aparecen desde el Neolítico con ejemplos como la Cueva de los Mármoles (Priego), CV-3 (Cogollos-Vega) o la Cueva de la Carigüela (Píñar), entre otros (Maicas 2007: 136). Son un tipo recurrente en El Malagón y en Los Millares en el III milenio a.C., y en el II milenio se documentan en numerosos yacimientos del cuadrante sudeste de la península ibérica como Peñalosa, Cerro de la Encina, Motilla del Azuer (Altamirano 2013a: 148), Cerro de El Cuchillo o Tabaiá (López 2011: 369-372). En Los Castillejos, atendiendo principalmente al material de la última década del siglo $\mathrm{XX}$, se puede considerar un tipo fundamentalmente calcolítico, sobre todo el tipo sin canal medular visible, asociado de forma frecuente a cuernecillos de arcilla y pesas de telar.

Los punzones laminares sobre costilla son característicos del Paleolítico y del Neolítico-Calcolítico en diversas zonas de Europa (Camps-Fabrer et al. 1990). En España se documentan en el Neolítico en la Cueva de las Ventanas (Píñar) (Salvatierra 1982: 76) y ya en el Calcolítico en el Tarajal (Níjar), en el Cerro de la Virgen (Schüle 1980: lám. 2) y en El Malágon (Arribas et al. 1978: fig. 14c; Altamirano 2013a: 153). En el II milenio se encuentra este útil en particular en el Bronce Argárico y, de hecho, en Peñalosa se ha señalado una variante (Altamirano 2013a: 153). Los punzones laminares sobre hueso largo son útiles que aparecen, por lo menos, desde el Neolítico Final o inicio de la Edad del Cobre en contextos manchegos como Cueva Maturras (Ciudad Real) (Altamirano 2013a: 152), del Sudeste, Levante y Murcia (Pascual 1998: 110-115; Maicas 2007: 142-144). J. A. López (2011: 378) indica casos ya del II milenio en Cabezo Redondo y Cerro del Cuchillo. Como en los casos anteriores la mayoría de los objetos recuperados en las excavaciones más recientes de Los Castillejos se adscriben al Calcolítico o a los momentos inmediatamente anteriores.

El uso de las agujas tiene evidencias ya en el Paleolítico Superior (Pascual 1998: 60) y en todas las fases 
del Neolítico valenciano (hasta el III milenio a.C.) hay hallazgos como ejemplifican Cova d'en Pardo (Planes), Ereta del Pedregal (Navarrés), Jovades (Cocentaina), Or (Beniarrès) o Sarsa (Bocairent) (Pascual 1998: 5960). En el Sudeste se dan al menos desde el Neolítico Reciente y Calcolítico como muestran los hallazgos en tumbas del valle del Almanzora, los Blanquizares (Lébor), Campos y Almizaraque (Cuevas del Almanzora) (Maicas 2007: 149) o El Malagón (Altamirano 2013a: 159). En todo el cuadrante sudeste de la península ibérica continúan ya en contextos de la Edad del Bronce como el Cerro de la Encina, Peñalosa (Altamirano 2013a: 159), Cabezo Redondo, Cerro del Cuchillo (López 2011: 390) o Motilla de Los Palacios (Almagro) (Nájera y Molina 1977: 272; Altamirano 2013a: 159).

Las puntas de proyectil se han documentado ampliamente en Europa y el elemento encontrado en Los Castillejos presenta parecidos con objetos más tardíos, de la Edad del Bronce, hallados por ejemplo en la Motila del Azuer, en El Argar, (Altamirano 2013a: 155-165), San Antón (Orihuela) y Cerro del Cuchillo (López 2011: 400-401).

Los biselados son útiles que aparecen en los registros arqueológicos del III milenio del Sudeste por ejemplo en Almizaraque y Terrera Ventura (Tabernas) (Maicas 2007: 161), pero también en el área levantina (Pascual 1998: 79-80), y en el resto del cuadrante sudeste de la Península J. A. López (2011: 410) señala artefactos más recientes hallados en el Cerro del Cuchillo o en Cabezo Redondo.

Los útiles romos sobre costilla de bóvido se documentan en España en el Neolítico y Calcolítico del Sudeste (Maicas 2007: 159) y Levante (Pascual 1998: 70). En particular en Andalucía se han encontrado en contextos neolíticos en Cueva CV-3 y Cueva de los Mármoles (Priego) (Maicas 2007: 159), mientras que son ejemplos de la Edad Bronce los de Cabezo Redondo y Cerro del Cuchillo (López 2011: 423), en otras zonas del sur de la península ibérica.

En cuanto al mango MF610242, obtenido por el aserrado de ambos extremos de la diáfisis, tiene paralelos con útiles hallados en Almizaraque, Campos y la tumba 40 de Los Millares (Maicas 2007: 166). El mango en asta de ciervo de las intervenciones de los años $70 \mathrm{del}$ siglo XX encuentra paralelos con útiles calcolítiocs de Almizaraque y del II milenio a.C. como los de Cabezo Redondo o El Oficio (Altamirano 2013a: 167).

Las gradinas son un tipo de útil que se documenta en contextos neolíticos y del Bronce Final de Europa y en el Neolítico del Próximo Oriente (Pascual 1998: 86). En la península ibérica los ejemplos más cercanos en el tiempo y en el espacio al artefacto MF69721 son los de la Cueva de los Murciélagos (Zuheros) (Vicent y Muñoz 1973: fig. 3) y la Cueva de los Murciélagos (Albuñol) (López 1980: 171).

Los peines se difunden entre el Neolítico Inicial y la Edad del Bronce (Castro 1988) y tienen amplia distribución geográfica, siendo numerosos en Próximo Oriente, Egipto e Italia, y escasos en Francia y en Alemania (Maicas 2007: 157). En la península ibérica se encuentran ejemplares en madera, hueso y marfil hasta la Edad del Bronce, en varios contextos como Los Millares, El Oficio, Fuente Álamo, El Argar, Cabezo Redondo o Blanquizares, continuando su distribución por el resto de Levante y el Valle del Ebro (López 2011: 476-477; Maicas 2007: 156-157). Los ejemplares estudiados muestran fuertes analogías morfológicas con los de Los Millares (Leisner y Leisner 1943: lám. 9, 10).

Los colgantes rectangulares o subrectangulares presentan una amplia difusión en Europa (Pau y Cámara 2018: 237) y en España encontramos adornos confeccionados en piedra, hueso o en concha en toda la zona oriental (Pascual 1998: 141), con algunos ejemplos neolíticos en Andalucía en la Cueva de la Carigüela y en la Cueva de los Murciélagos (Albuñol) (Maicas 2007: 178). Al igual que estos hallazgos, los colgantes de Los Castillejos se adscriben a momentos neolíticos y casi todos ellos proceden de contextos entre fines del VI y principios del V milenio a.C.

Los colmillos de suido, documentados como adornos, están bien documentados en Europa con una amplia difusión cronológica. En la península ibérica se hallan desde el III hasta el II milenio a.C. en varias zonas como el Sudeste, Levante (Maicas 2007: 177; López 2011: 448-451; Pau 2016: 638-643), La Mancha (Altamirano 2013a: 174), valle del Ebro y Cataluña (Maicas 2007: 177).

Los colgantes de hueso entero son escasos en la península ibérica (Pascual 1998: 136) y no hemos encontrado todavía un adorno que pueda compararse morfológicamente al hallado en Los Castillejos.

Las cuentas cilíndricas constituyen un grupo de adornos conocido en Europa en un amplio periodo cronológico, por lo menos hasta la Edad del Bronce (Maicas 2007: 183; Pascual 1998: 121). En España están bien representadas en las zonas de Levante (Pascual 1998: 121; López 2011: 446), Valle del Ebro (Pérez y López de la Calle 1986), Sudeste (Maicas 2007: 183; López 2011: 446; Altamirano 2013a: 170; Pau 2016: 681-686) y La Mancha (López 2011: 446; Altamirano 2013a: 170). 
El elemento anular en hueso de forma abultada MF65226 muestra una morfología muy conocida en Andalucía oriental en todas las fases neolíticas, como muestran los hallazgos de las cuevas de Carigüela, Mármoles y Huerta Anguita (Priego) (Pascual 1998: 156), Murciélagos (Zuheros) (Pascual 1998: 156), Agua (Alhama) (Salvatierra 1982: 81) y Nerja (Pascual 1998: 156).

Los botones derivados de la esfera están presentes en una zona geográfica muy amplia, que incluye casi toda Europa centro-occidental (Guilaine 1963; Ferrarese Ceruti 1974; Pérez y López de Calle 1986; Uscatescu 1992; Pau 2016: 704-708), pero es complicado hacer una diferenciación por tipos, ya que muchos autores hablan en general de botones hemisféricos. En España, los botones de Los Castillejos encuentran parecidos formales con los recuperados en el Cerro de la Virgen (Pau 2016: 705-706; Pau et al. 2018: 272) y con el de Moncín (Rodanés 1987: Lám. 30, 61. 3).

Los botones con apéndices laterales son característicos del Campaniforme europeo, concentrándose en los grupos mediterráneos (Lemercier 2002; Salanova 2005). El botón MF3203 de Los Castillejos encuentra paralelos con el botón V1440 del Cerro de la Virgen (Pau 2016: 716-717; Pau et al. 2018: 272), con botones sardos (Pau y Molina 2015: 101) y con los de la gruta 1 de Sâo Pedro do Estoril (Cascais) (Gonçalves 2005). El objeto MF6153 tiene similitudes con uno de los botones de Vila Nova de São Pedro (Azambuja) (Paço 1960: fig. 5,3).

Aunque los botones cilíndricos son poco frecuentes (Uscatescu 1992: 63), en Campos (Cuevas del Almanzora) se documenta una pieza que presenta la misma forma que el de Los Castillejos y hay otros ejemplos de zonas más lejanas como los de Las Pozas (Casaseca de Las Chanas) y Galet, en Francia. Todos los ejemplares son de marfil y se adscriben al periodo campaniforme (Maicas 2007: 172).

Los botones cónicos los encontramos desde el nordeste al sudoeste de Europa y hasta Irán (Uscatescu 1992: 102-103), habitualmente asociados a cerámica campaniforme (Delibes 1977: 177; Uscatescu 1992: 37 , 62) y en el Cerro de la Virgen aparecen desde las primeras fases de su desarrollo (IIA) (Pau et al. 2018: 285), siendo los botones de Los Castillejos también del Cobre Tardío. El MF2260 encuentra fuertes parecidos con el de Son Mulet (Llucmajor) (Veny 1968: 80) mientras que el MF22 los tiene con uno hallado en Monte de Varzea (Aljezur) (Leisner y Leisner 1943).

Los botones piramidales aparecen en toda Europa occidental (Uscatescu 1992: 103) y los de Los
Castillejos encuentran parecidos con los recuperados en Cerro de la Virgen (Pau 2016: 722-724; Pau et al. 2018: 273) y con algunos ejemplares de Falguera (Alcoi) manufacturados en marfil y en concha (Pau 2016: 724).

Los botones prismáticos se documentan en el Mediterráneo noroccidental y sur de Polonia, con fuerte concentración en la península ibérica (Uscatescu 1992: 75, $103,104)$, por lo que se ha planteado su origen en el Pirineo oriental (Pérez y López de Calle 1986; Ontañón 2002: 110). Los botones de Los Castillejos recuerdan los del Cerro de la Virgen y los de la Falguera y Gatz (Alzira) (Pau 2016: 725-728; Pau et al. 2018: 273-275).

Los alfileres cilíndricos con cabeza no diferenciada están documentados también desde finales del IV y principios del III milenio a.C. (Altamirano 2013a: 148) y hay ejemplos en el Sudeste, en Almizaraque, en tumbas megalíticas de Purchena o en la tumba 2 de la Rambla de Huéchar (Gádor) (Maicas 2007: 144), y en Levante (Pascual 1998: 111), perdurando en la Edad del Bronce, como ejemplifica Peñalosa (Altamirano 2013a: 149).

Los alfileres con cabeza diferenciada fija espatulada son adornos documentados ampliamente en Europa desde el Neolítico Medio hasta la Edad de los Metales (Pascual 1998: 113), en particular se concentran en la Edad del Cobre del Sudeste (Altamirano 2013a: 149), como en Almizaraque (Maicas 2007: 146), Cerro de la Virgen (Schüle 1980: lám.1) Ciavieja (El Ejido) (Carrillero y Suárez 1990) y El Malagón (Arribas et al. 1978: fig. 14a; Salvatierra 1982; Altamirano 2013a: 149), pero aparecen también por ejemplo en la Cueva de Nerja (Rodanés 1987: fig. 90) y en contextos de la Edad del Bronce del sur peninsular como Cabezo Redondo y Cerro del Cuchillo (López 2011: 387). En este caso, aun con el predominio de este tipo de objetos en contextos calcolíticos de Los Castillejos, según los datos de las excavaciones de los años 90 del siglo XX, el ejemplar 69204 apoya la existencia al menos de este tipo desde contextos neolíticos, aunque sea de fines del $\mathrm{V}$ milenio a.C.

Los alfileres con cabeza acanalada aparecen en la península ibérica en la Comunidad Valenciana y en el Sudeste, y, sobre todo, en Portugal (Pascual 1998: 113), pero se encuentran también en contextos extrapeninsulares y, por la fuerte analogía con los ejemplares estudiados de Los Castillejos, podemos citar un ejemplo de la Tumba I de Ponte Secco (Porto Torres) (Contu 1955: 32; Pau 2016: 736-737).

Las falanges decoradas aparecen ya en registros arqueológicos paleolíticos y otros ejemplos más recientes 
se encuentran en el suroeste de Rumanía y en Próximo Oriente (Maicas 2007: 117). En la península ibérica los ídolos falanges caracterizan el Cobre Antiguo y llegan hasta la época Campaniforme (Escoriza 1990: 97), como sucede en Los Castillejos, desde el Sudeste hasta áreas del valle del Guadalquivir y la cuenca media del Guadiana (Ortiz y Blasco 2000: 275).

Ídolos planos con escotaduras laterales se han hallado en el Sudeste, en la Meseta sur, en contextos valencianos e incluso en Tarragona (Pascual 1998: 187), desde el Neolítico avanzado hasta la Edad del Bronce (Pascual 1998: 187).

Aunque son escasas las trazas de uso identificadas en los útiles estudiados, por analogías con piezas de otros yacimientos, por su localización y por su forma podemos proponer su posible funcionalidad. Por ejemplo, los punzones pudieron emplearse para atravesar de forma manual o pinchar. En, el caso de los punzones calcolíticos, su asociación a pesas de telar de forma trapezoidal, placas, cuernecillos y fusayolas, nos invita a sugerir que pueden estar relacionados con actividades textiles.

A partir del estudio tipológico y traceológico ha sido posible proponer la manera de usar los adornos. Los colgantes, las cuentas y los elementos anulares se utilizarían para confeccionar adornos complejos como collares y pulseras, o para decorar la cabeza o las vestimentas, los botones se utilizarían como botones propiamente dichos, o como colgantes.

\section{CONCLUSIONES}

Algunos tipos de objetos aparecen solo en las fases neolíticas (colgantes rectangulares) y, si atendemos únicamente a los datos de las campañas de los años 90 del siglo XX, tal vez los punzones sobre hueso hendido que conservan media epífisis también sean exclusivamente neolíticos. Otros objetos se constatan solo a partir del Calcolítico o inmediatamente antes (punzones facetados sin canal medular visible, punzones laminares sobre costilla, peines, agujas, alfileres con cabeza diferenciada fija e ídolos). Además, los botones aparecen por primera vez en el Cobre Tardío y en particular su forma prismática se constata por primera vez en el Bronce Antiguo.

Los pocos artefactos decorados encontrados en el yacimiento (un punzón, tres indeterminados, dos cabezas de alfiler, un botón) coinciden en sus técnicas y motivos, líneas paralelas incisas, rectas u oblicuas.
Las analogías formales de estos artefactos con varias zonas de Europa y en particular con otros yacimientos del cuadrante sudeste de la península ibérica nos indican la existencia de contactos incluso a larga distancia (directa o indirectamente), lo que explicaría la presencia de adornos (colgante rectangular y botones) en marfil, el primero de una fecha neolítica sorprendentemente temprana.

Para la manufactura de los otros artefactos se utilizaron como soporte huesos, dientes y colmillos de animales autóctonos domésticos o salvajes, existiendo cierta predilección por especies y partes anatómicas según el útil a conseguir. Así, las costillas de bóvidos se usaron para colgantes, elementos dentados y punzones, los colmillos de suido para colgantes y las fíbulas para punzones y agujas, mientras las astas de cérvidos para mangos, botones y apuntados.

Los estudios traceológicos han identificado, especialmente, las últimas fases de manufactura y se han reconocido procesos de reparación en adornos bien por su valor simbólico y/o las dificultades de acceso a la materia prima. En algunos casos, la asociación de elementos, y no solo su forma o las trazas presentes, ayuda a proponer un uso determinado. De esta forma, en el caso de los punzones y tal vez de los alfileres de cabeza fija de las fases calcolíticas, la proximidad a diferentes tipos de pesas sugiere su relación con diferentes fases de las actividades textiles.

\section{Agradecimientos}

Este estudio ha sido realizado gracias a la ayuda del Proyecto "Cronología de la consolidación del sedentarismo y la desigualdad social en el Alto Guadalquivir" (HAR2008-04577), financiado por el Ministerio de Ciencia e Innovación.

\section{BIBLIOGRAFÍA}

Aguayo, P. (1986): "La transición de la Edad del Cobre a la Edad del Bronce en la provincia de Granada”, en Homenaje a Luis Siret (Cuevas de Almanzora, 1986): 262-270. Sevilla, Junta de Andalucía.

Altamirano, M. (2013a): Hueso, asta, marfil y concha: aspectos tecnológicos y socioculturales durante el III y el II milenio a. C. En el Sur de la Península Ibérica. Tesis Doctoral, Universidad de Granada. Inédita. 
Altamirano, M. (2013b): "Un hacha-martillo sobre asta de ciervo de inicios del III milenio a.C., procedentes del poblado de Los Castillejos en Las Peñas de los Gitanos (Montefrío, Granada). Estudio tecnológico y funcional”. Antiquitas 25: 29-38. https:// drive.google.com/file/d/0Bz1J47_lbMqcWX14VHAtcjBKSkU/view

Altamirano, M. (2014a): "Hueso, asta y marfil: manufactura de artefactos durante el III milenio a. C. en el poblado de los Castillejos (Montefrío, Granada)". Saguntum 46: 21-40. https://doi.org/10.7203/SAGVNTVM.46.3266

Altamirano, M. (2014b): "Los peines óseos de los Castillejos en Las Peñas de los Gitanos (Montefrío, Granada)", en Actas del II Congreso de Prehistoria de Andalucía: 361-370. Antequera (2012), Sevilla, Junta de Andalucía.

Altamirano, M. (2014c): “Uso y mantenimiento de objetos. Botones y peines de marfil, hueso y asta de ciervo de los Castillejos (Montefrío, Granada)". Antiquitas 26: 157-162. https://drive.google.com/file/ d/0Bz1J47_lbMqcUmVqVTRSMVhCZU0/view

Arnal, J. (1973): "Sur les Dolmens et Hypogées des Pays Latins: Les V-Boutons", en G. Daniel, P. Kjaerum (coords.), Megalithic Graves and Ritual. Papers presented at the III Atlantic Colloquium. Jutland Archaeological Society Publications XI: 221-227. København, Gyldendal.

Arribas, A. y Molina, F. (1978): El poblado de Los Castillejos en las Peñas de los Gitanos (Montefrio, Granada). Campaña de excavaciones de 1971. El corte $n^{\circ} 1$. Cuadernos de Prehistoria de la Universidad de Granada. Serie Monográfica 3: 67-87. Granada, Universidad de Granada. http://revistaseug. ugr.es/index.php/cpag/article/view/732/931

Arribas, A. y Molina, F. (1979): "Nuevas aportaciones al inicio de la metalurgia en la Península Ibérica. El poblado de Los Castillejos de Montefrío (Granada)", en Proceedings of the Fifth Atlantic Colloquium, (Dublin, 1979): 7-34. Dublin, Stationery Office.

Arribas, A.; Molina, F.; Torre, F.; Nájera, T. y Saéz, L. (1978): "El poblado de la Edad del Cobre de El Malagón (Cullar-Baza, Granada)". Cuadernos de Prehistoria de la Universidad de Granada 3: 67-116. http:// revistaseug.ugr.es/index.php/cpag/article/view/732

Barge H; Bellier C.; Camps Fabrer; H, Catellain P.; Mons L.; Provenzano N. y Taborin Y. (1991): $\mathrm{Ob}$ jets de parure. Fiches typologiques de l'industrie osseuse préhistorique. Cahier IV. Aix en Provence,
Publications de l'Université de Provence, Aix-Marseille 1.

Bonnardin, S. (2009): La parure funéraire au Néolithique ancien dans les Bassins parisiens et rhénans. Rubané, Hinkelstein et Villeneuve-Saint-Germain. París, Société Préhistorique Française.

Cacho, C.; Papí, C.; Sánchez-Barriga, A. y Alonso, F. (1996): "La cestería decorada de la cueva de los Murciélagos, (Albuñol, Granada)". Complutum Extra 6(1): 105-122. https://revistas.ucm.es/index. php/CMPL/article/view/CMPL9696230105A

Cámara, J. A.; Afonso, J. A. y Molina, F. (2016): “La ocupación de Las Peñas de los Gitanos (Montefrío, Granada) desde el Neolítico al mundo romano. Asentamiento y ritual funerario", en R. Pedregosa (coord.), Arqueología e Historia de un paisaje singular. La Peña de los Gitanos, Montefrío (Granada): 17-121. Montefrío, Ayuntamiento de Montefrío.

Camps Fabrer, H.; Ramseyer, D.; Stordeur, D.; Buisson, D. y Provenzano, N. (1990): Poiçons, pointes, poignards, aiguilles. Fiches typologiques de l'industrie osseuse préhistorique. Cahier III. Aix en Provence, Publications de l'Université de Provence, Aix-Marseille 1.

Carrillero, M. y Suárez, Á. (1990): “Ciavieja: El Ejido, Almería: resultados obtenidos en las campañas de 1985 y 1986: el poblado de la Edad del Cobre". Cuadernos de Prehistoria de la Universidad de Granada 14-15: 109-136. http://revistaseug.ugr.es/ index.php/cpag/article/view/1291

Castro, Z. (1988): "Peines prehistóricos peninsulares". Trabajos de Prehistoria 45: 243-258. https://doi. org/10.3989/tp.1988.v45.i0.613

Delibes, G. (1977): El Vaso Campaniforme en la meseta norte española. Studia Archaeologica 46. Valladolid, Universidad de Valladolid.

Escoriza, T. (1990): "Ídolos de la Edad del Cobre del yacimiento de las Angosturas (Gor, Granada)". Zephyrus 43: 95-100. http://revistas.usal.es/index. php/0514-7336/article/view/1930/1986

Ferrarese Ceruti, M. L. (1974): "La tomba XVI di Su Crocifissu Mannu e la cultura di Bonnanaro". Bulletino di Paletnologia Italiana 8: 113-210.

Gómez-Moreno, M. (1949): Misceláneas, Historia-ArteArqueología. Primera Serie. La Antigüedad. Madrid, Consejo Superior de Investigaciones Científicas.

Góngora, M. de (1991): Antigüedades prehistóricas de Andalucía (Reedición Facsímil). Granada, Universidad de Granada. 
Gonçalves, V. S. (coord.) (2005): Cascais há 5000 anos. Cascáis, Camara Municipal, Cascáis.

Guilaine, J. (1963): "Boutons perforés en V du Chalcolithique pyrénéen". Bulletin de la Société préhistorique française 60 (11-12): 818-827. www.persee. fr/doc/bspf_0249-7638_1963_num_60_11_3959

Harrison, R. J. (1977): The Bell Beakers cultures of Spain and Portugal. Cambridge, Peabody museum of Archaeology and Ethonology, Harvard University.

Jover J. y López J. A. (2013): “La producción textil durante la edad del Bronceen el cuadrante Suroriental de la Península Ibérica: materias primas, productos, instrumentos y procesos de trabajo". Zephyrus LXXI: 149-171. http://revistas.usal.es/index.php/0514-7336/article/view/9961/11893

Leisner, G. y Leisner, V. (1943): Die Megalithgräber der Iberischen Halbinsel. Der Süden. RömischGermanische Forschungen 17. Berlin, Deutsches Archäologisches Institut.

Lemercier, O. (2002): Le Campaniforme dans le sudest de la France. De l'Archéologie à l'Histoire du Troisième millénaire avant notre ère. Tesis Doctoral, L'Universite Aix-Marseille I. https://tel.archives-ouvertes.fr/tel-00087323

López, J. A. (2006): “Consideraciones en torno al Horizonte Campaniforme de Transición”. Archivo de Prehistoria Levantina 26: 193-244. http://www.museuprehistoriavalencia.es/web_mupreva_dedalo/ publicaciones/774/es

López, J. A. (2011): Asta, hueso y marfil: artefactos óseos de la Edad del Bronce en el Levante y Sureste de la Península Ibérica (c2500-c1300 cal BC). Marq. Serie mayor 9. Alicante, Museo Arqueológico de Alicante.

López, P. (1980): "Estudio de la cerámica, industria ósea, y lítica de la Cueva de los Murcielagos de Albuñol (Granada)". Trabajos de Prehistoria 37: 163-180.

Maicas, R. (2007): Industria ósea y funcionalidad: Neolítico y Calcolítico en la cuenta de Vera (Almería). Bibliotheca Praehistorica Hispana 24. Madrid, Consejo Superior de Investigaciones Científicas.

Mergelina, C. de (1941-42): "La estación arqueológica de Montefrío (Granada). I: Los dólmenes". Boletín de la Sociedad de Arte y arqueología VIII: 33-106.

Mergelina, C. de (1945-46): "La estación arqueológica de Montefrío (Granada). II: La acrópolis de Guirrete (Los Castillejos)". Boletín de la Sociedad de Arte y arqueología XII: 15-26
Molina, F.; Cámara, J. A.; Afonso, J. A.; Gámiz, J.; Capel, J. y Martínez, G. (2017): "Hiatus in an archaeological multilevel site: Los Castillejos in Las Peñas de los Gitanos (Montefrío, Granada)", en M. Cupitò, M. Vidale y A. Angelini (coords.), Beyond Limits, Studi in onore di Giovanni Leonardi: 91-100. Padova, Università degli Studi di Padova.

Moreno, M. A. (1982): "Los materiales arqueológicos del poblado de Los Castillejos y Cueva Alta (Montefrío), procedentes de las excavaciones de 1946 y 1947". Cuadernos de Prehistoria de la Universidad de Granada 7: 235-266. http://revistaseug.ugr.es/ index.php/cpag/article/view/1202

Nájera, T. y Molina, F. (1977): "La Edad del Bronce en la Mancha. Excavaciones en las Motillas del Azuer y Los Palacios (Campaña de 1974)". Cuadernos de Prehistoria de la Universidad de Granada 2: 251-300. http:// revistaseug.ugr.es/index.php/cpag/article/view/727

Oliva, M. (2015): Aprofitament i transformació de matèries preimeres pera l'elaboració d'ornaments durant la prehistòria recent (5600-3400 cal. Ane) al nord-est de la península Iberica. Tesis Doctoral, Universitat Autònoma de Barcelona. https://www. tdx.cat/handle/10803/325679

Ontañón, R. (2002): “Un botón prismático con doble perforación en $\mathrm{V}$ inédito procedente del dolmen de Pagobakoitza, en el contexto de los elementos de adorno del Calcolítico Cantábrico". Munibe (Antropologia-Arkeologia) 54: 103115. http://www.aranzadi.eus/fileadmin/docs/ Munibe/2002103115AA.pdf

Ortiz, M. y Blasco, F. (2000): "Los ídolos-falange del Tholos de Huerta Montero (Almendralejo)". Extremadura Arqueológica VIII: 267-289.

Paço, A. (1960): "Castro de Vila Nova de Sao Pedro. XII. Algunos objetos de osso o marfil". Zephyrus XI: 105-117. http://revistas.usal.es/index.php/05147336/article/view/371/549

Pascual, J. L., (1998): Utillaje óseo, adornos e ídolos del Neolítico valenciano. Serie de Trabajos Varios del Servicio de Investigación Prehistórica 95. València, Museu de Prehistòria de València,

Pau, C. (2012a): Adornos campaniformes y epicampaniformes de Cerdeña. Estudio morfológico, tecnológico y funcional. Berlín, Editorial Académica Española.

Pau, C. (2012b), "Los botones campaniformes sardos y sus analogías con los adornos de la Península Ibérica y de otras zonas del Mediterráneo". Saguntum 44: 67-76. https://doi.org/10.7203/SAGVNTVM 
Pau, C. (2015): "Los ornamentos en materia ósea del neolítico en el poblado de Los Castillejos de Montefrío", en V.S. Gonçalves, M. Diniz y A. C. Sousa (coords), $5^{\circ}$ Congresso do Neolítico Peninsular:, pp. 415-418. Lisboa (2011), Lisboa, Universidade de Lisboa.

Pau, C. (2016): Los objetos de adorno en el Mediterráneo occidental en época Campaniforme y su trascendencia social. Tesis Doctoral, Universidad de Granada. http://hdl.handle.net/10481/43488

Pau, C. y Cámara, J. A. (2018): “Los primeros objetos de adorno personal de la prehistoria reciente del poblado de Los Castillejos en Las Peñas de los Gitanos (Montefrío, España)". Arqueología 24(2): 209246. http://revistascientificas.filo.uba.ar/index.php/ Arqueologia/article/view/5007/4521

Pau, C. y Molina, F. (2015): "Los botones con perforación en "v" del poblado de los Castillejos de Montefrío". Bollettino di arqueología VI (1): 89-110. http://bollettinodiarcheologiaonline.beniculturali. it/wp-content/uploads/2018/12/VI-2015-1-3.-PauGonzalez-.pdf

Pau, C.; Morillo, J.M.; Cámara, J.A. y Molina, F. (2018): "Los objetos de adorno en marfil del yacimiento del Cerro de la Virgen (Orce, Granada)". Complutum 29 (2): 267-298. https://doi. org/10.5209/CMPL.62581

Pérez, C. L. y López de Calle, C. (1986): "Relaciones culturales en el Eneolítico del Valle del Ebro a partir de un análisis específico sobre elementos de adorno en yacimientos riojanos", en Segundo Coloquio sobre historia de la Rioja 1 (Logroño, 1985): 19-36. Logroño, Universidad de La Rioja.

Ramos, U.; Afonso, J. A.; Cámara, J. A.; Molina, F. y Moreno, M. (1997): "Trabajos de acondicionamiento y estudio científico en el yacimiento de Los castillejos en las Peñas de Los Gitanos (Montefrío,
Granada)". Anuario Arqueológico de Andalucía 1994 (III): 246-252. https://www.juntadeandalucia. es/organismos/culturaypatrimoniohistorico/areas/ bienes-culturales/actividades-arqueologicas/anuario-arqueologico.html

Rodanés, J. M. (1987): La industria ósea prehistórica en el Valle del Ebro (Neolitico- Edad del Bronce). Zaragoza, Diputación General de Aragón.

Salanova, L. (2005): "Los orígenes del Campaniforme: Descomponer, analizar, cartografiar", en M.A. Rojo, R. Garrido, e Y. García (coords.), El Campaniforme en la Península Ibérica y su contexto europeo: 7-18. Valladolid, Universidad de Valladolid.

Salvatierra, V. (1982): El hueso trabajado en Granada (Del Neolítico al Bronce). Tesis Doctoral, Universidad de Granada. Inédita.

Schüle, W. (1980): Orce und Galera: zwei Siedlungen aus dem 3 bis 1 Jahrtausend v. Chr. Im Südosten der Iberischen Halbinsel I: übersicht über die Ausgrabungen 1962-1970. Mainz am Rhein, Phillip von Zabern.

Tarradell, M. (1952): "Edad del Bronce en Montefrío (Granada). Resultados de las excavaciones en yacimientos de Las Peñas de los Gitanos". Ampurias XIV: 49-80. https://www.raco.cat/index.php/Empuries/article/view/99232/164134

Uscatescu, A. (1992): Los botones de perforación en " $V$ " en la Península Ibérica y las Baleares durante la Edad de los Metales. Madrid, FORO.

Veny, C. (1968): Las cuevas sepulcrales del Bronce antiguo de Mallorca. Biblioteca Praehistorica Hispana IX. Madrid, Consejo Superior de Investigaciones Científicas.

Vicent A.M. y Muñoz A. M. (1973): Segunda campaña de excavaciones, La Cueva de Los Murciélagos, Zuheros (Córdoba), 1969. Excavaciones Arqueológicas en España 77. Madrid, Ministerio de Educación y Ciencia. 